IZA DP No. 8889

Scars of Recessions in a Rigid Labor Market

Bart Cockx

Corinna Ghirelli

February 2015

Forschungsinstitut zur Zukunft der Arbeit Institute for the Study of Labor 


\title{
Scars of Recessions in a Rigid Labor Market
}

\author{
Bart Cockx \\ SHERPPA, Ghent University, \\ IRES, CESifo and IZA \\ Corinna Ghirelli \\ IRES, Université catholique de Louvain \\ and SHERPPA, Ghent University
}

\section{Discussion Paper No. 8889 February 2015}

\author{
IZA \\ P.O. Box 7240 \\ 53072 Bonn \\ Germany \\ Phone: +49-228-3894-0 \\ Fax: +49-228-3894-180 \\ E-mail: iza@iza.org
}

\begin{abstract}
Any opinions expressed here are those of the author(s) and not those of IZA. Research published in this series may include views on policy, but the institute itself takes no institutional policy positions. The IZA research network is committed to the IZA Guiding Principles of Research Integrity.

The Institute for the Study of Labor (IZA) in Bonn is a local and virtual international research center and a place of communication between science, politics and business. IZA is an independent nonprofit organization supported by Deutsche Post Foundation. The center is associated with the University of Bonn and offers a stimulating research environment through its international network, workshops and conferences, data service, project support, research visits and doctoral program. IZA engages in (i) original and internationally competitive research in all fields of labor economics, (ii) development of policy concepts, and (iii) dissemination of research results and concepts to the interested public.
\end{abstract}

IZA Discussion Papers often represent preliminary work and are circulated to encourage discussion. Citation of such a paper should account for its provisional character. A revised version may be available directly from the author. 
IZA Discussion Paper No. 8889

February 2015

\section{ABSTRACT}

\section{Scars of Recessions in a Rigid Labor Market}

We study the impact of graduating in a recession in Flanders (Belgium), i.e. in a rigid labor market. In the presence of a high minimum wage, a typical recession hardly influences the hourly wage of low educated men, but reduces working time and earnings by about $4.5 \%$ up to twelve years after graduation. For the high educated, the working time is not persistently affected, but the penalty on the hourly wage (and earnings) increases with experience, and attains roughly $-6 \%$ ten years after labor market entry. We also contribute to the literature on inference with few clusters.

JEL Classification: C12, C41, E32, I21, J22, J23, J31, J6

Keywords: $\quad$ scars, graduating, labor market rigidity, recession, few clusters, cluster robust

Corresponding author:

Bart Cockx

SHERPPA,

Ghent University

Tweekerkenstraat 2

B-9000 Gent

Belgium

E-mail: Bart.Cockx@UGent.be 


\section{Introduction}

The Great Recession in 2008 and its devastating impact on youth unemployment spurred the debate on the long-term effects of economic downturns on the career prospects of young graduates. In the current public debate the dominant viewpoint is that the Great Recession creates a lost generation. But is this view evidence based? Economic research has only relatively recently started investigating this question, exploring data on past recessions in various countries. For instance, Kahn (2010), Oreopoulos et al. (2012), and very recently Altonji et al. (2014) show that in North-America adverse initial conditions push college graduates into initial lower-quality placements and that this translates into long-term penalties on earnings or wages. In Europe, e.g. Raaum and Røed (2006) in Norway, Kwon et al. (2010) in Sweden, and Brunner and Kuhn (2014) in Austria reach similar conclusions. More generally, existing evidence broadly confirms the conjecture that a recession ${ }^{1}$ has persistent impact on labor market outcomes of young graduates, although the magnitude and persistence of these effects depend much on the considered outcome (employment, wage, earnings,...), the level of educational attainment, and the institutional environment (see Section 2). This study analyses various of these dimensions in a unique employer-employee dataset that matches survey and administrative data on a sample of male school graduates in Flanders, the most prosperous of three regions in Belgium.

The case of Belgium is particularly interesting, because labor market rigidity, as measured by flows in and out of unemployment, is among the highest in OECD. For instance, the average monthly job destruction rate between 1990 and 1999 was less than $0.5 \%$ of the labor force, while expected unemployment duration exceeded 20 months. These figures are comparable to the Italian, but contrast with those of the much more flexible US labor market, where $1.25 \%$ jobs were destroyed every month and the mean unemployment duration was as low as five months (Pérez and Yao, 2015). The research of Genda et al. (2010), and more recently, of Kawaguchi and Murao (2014) suggests that the effects of graduating during a recession are much more persistent in a rigid labor market than in a flexible one. Our study provides further valuable evidence on this hypothesis. Moreover, since in Belgium the sources of this rigidity differ according to skill level, we can obtain some insights in how distinct sources of rigidity drive different hysteresis mechanisms. For high skilled workers the rigidity is predominantly induced by the very strict employment protection legislation (EPL) for white collar workers. But this does not apply for low skilled workers, since they are usually employed as blue collar workers for whom, until very recently, EPL was very loose. For low skilled youth, (sectoral) minimum wages that are among the highest of OECD, and lenient short-time work compensation (STC) and unemployment insurance (UI) systems are therefore more relevant sources of rigidity.

In line with the institutional setting, we find that adverse labor market conditions hardly

\footnotetext{
${ }^{1}$ In line with the aforementioned literature, a "recession" refers to a situation of adverse labor market conditions as measured by a rise in the unemployment rate rather than to a decline of real GDP.
} 
affect hourly wages of low educated youth and that nearly all the burden of the adjustment runs through the annual number of hours worked, predominantly induced by more unemployment experience. The negative impact matters more in the first years after graduation, but it persists up to 12 years later. This is in line with the ample evidence that experiencing unemployment (early in the career) inflicts long-term scars on labor market outcomes (e.g. Arulampalam, 2001; Gregg, 2001, Gregg and Tominey, 2005; Schmillen and Umkehrer, 2013).

For high educated youth, minimum wages are in general not binding, STC is not available, and replacement rates in UI are relatively low, so that a different hysteresis mechanism is operating. A recession may force high educated youth to downgrade and accept lower quality jobs paying lower wages. Those who refuse to downgrade become temporarily unemployed. The possibility of catching-up with a more fortunate generation that did not graduate in a recession is hampered by a slower pace of human capital accumulation in these lower quality jobs (Gibbons and Waldman, 2006), by rigidities induced by long-term contracting (Beaudry and DiNardo, 1991; Baker et al., 1994), or by search frictions that increase with age or job tenure, inducing workers to stop searching for a better paying job (Oreopoulos et al. 2012). The very strict EPL for white collar workers in Belgium increases the gradient of search frictions with age or job tenure. Hence, we find much more persistence in hourly wages and earnings of the high skilled in Belgium than in the more flexible North American labor markets.

Our study does not only provide insights in how distinct sources of rigidity drive different hysteresis mechanisms. It also contributes to the literature in other dimensions. First, we identify the long-run effects of recessions on labor market outcomes by exploiting the variation of the provincial unemployment rate between five provinces and eight graduation years (19942001 for the low educated and 1997-2004 for the high educated). This variation identifies the causal impact of recessions only to the extent that the provincial unemployment rate does not affect the composition of graduates in a province, either by changing the timing of graduation or by inducing inter-provincial mobility. We show that the latter is negligible and propose a new method for testing the former. The test is based on a discrete duration model relating the timing of graduation since the end of compulsory education to the provincial unemployment rate. We cannot reject the absence of such relationship.

Second, we have access to unusually rich data. Survey data are matched to comprehensive administrative data from the various institutions of the Belgian Social Insurance system. The survey data provides precise information on the timing of graduation, while the administrative data contain, up to twelve years after labor market entry, detailed information (hours worked, hourly wage and earnings) on salaried public and private sector employment, and also on time spent as self-employed worker. For salaried workers we have also information on the quality of the firm (as measured by the median wage). Existing research is often less comprehensive by 
focusing on particular labor market outcomes $2^{2}$ either wages or (salaried) employment, or by considering particular sub-populations (e.g. college graduates).

Third, we propose a new method of inference. Inference is complicated, since the regressor of interest, the provincial unemployment rate at graduation, is a serially correlated variable that is measured at a grouped level. Bertrand et al. (2004) demonstrate that in such circumstances the standard error can be severely downwards biased and that this bias can be very severe if the number of groups (clusters) is small. To address this problem, we propose a novel feasible generalized least squares (FGLS) method closely related to the efficient Minimum Distance (or Minimum Chi-square) estimator of Wooldridge (2006, 2010) for cross-section data and the FGLS recently introduced by Brewer et al. (2013) for difference-in-differences designs.

We organize our discussion as follows. In the next section we briefly review the literature on the scarring effects of graduating in downturns. Section 3 summarizes the institutional setting. In Section 4 we describe the data. In Section 5 the estimation strategy is explained, including the way in which we deal with the problem of inference in the presence of a small number of clusters. We report the results in Section 6. Section 7 concludes. We refer the reader to a Supplementary Online Appendix (http://users.ugent.be/ bcockx/Ascars.pdf) for a detailed description of the variables construction, the sample selection, the complete estimation results, as well as a description and the results of the tests for the endogeneity of the timing of graduation and of the inter-provincial mobility.

\section{Literature Review}

Researchers studying the long-term effects of graduating during recessions in North-America report different findings for high than for low skilled youth. Graduating from college during a recession imposes a modest but long-lasting penalty on earnings that gradually fades away in about ten years (for Canada, see Oreopoulos et al., 2012, and for the US, see Mansour (2009), $\operatorname{Kahn}$ (2010), Genda et al. 2010, and, very recently, Altonji et al. (2014) ) $3^{3}$ These earnings losses are essentially due to a decline in hourly wages, not in employment or hours worked. During a recession college graduates are forced to accept lower quality jobs paying lower wages and/or offering less career perspectives and less opportunities for promotion and training, since high quality career jobs are then in reduced supply. Workers can react to this set-back and catchup with the more lucky generations that graduated during booms by enhancing investments in human capital (Mroz and Savage, 2006), or by intensifying their search for higher paying jobs

\footnotetext{
2 Genda et al. (2010) and, very recently, [Altonji et al. (2014) are notable exceptions.

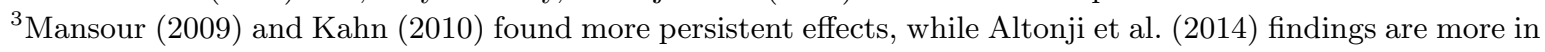
line with those of Oreopoulos et al. 2012 and Genda et al., 2010. In addition, these researchers provide evidence that the penalty differs by field of study, with high-paying majors being less affected by initial conditions than lower-paying ones, although less so during the Great Recession, when early impacts on earnings are reported to have much larger impacts than during past recessions.
} 
(Topel and Ward, 1992). However, the possibility of catching-up is hampered by hysteresis in career progression, both within and between firms. This can be due to imperfections in downward wage renegotiations of lucky generations that entered in a boom (Beaudry and DiNardo, 1991) 4 or to information imperfections (Baker et al., 1994), both shielding the internal labor market from the competitive forces in the external labor market. But also in the absence of long-term wage contracts, part of the acquired human capital in these lower quality jobs is task specific, leaving part of a worker's human capital unutilized when she gets promoted, and, hence, inducing lower wages many years later (Gibbons and Waldman, 2004, 2006). Moreover, search frictions that increase with age or job tenure can induce workers to stop searching for a better paying job (Oreopoulos et al., 2008, 2012).

For low skilled workers, by contrast, the effect of adverse labor market conditions at graduation has immediate important negative effects on wages and earnings, which fade away quickly after a couple of years, and a small and only marginally significant, though persistent, effect on employment. The number of hours worked is not affected (Genda et al., 2010). In a recent work, Speer (2014) documents also reports severe, but short-lived effects of leaving high school in a recession on wages (during the first four years) and on hours worked on the intensive and the extensive margin (lasting only two years) 5 This is because the labor market for low skilled workers involves less investments in human capital and long-term career contracts. It operates more like a spot market, in which wages rather than employment react rapidly to changes in the economic environment (see e.g. Kilponen and Santavirta (2010) and Devereux and Hart (2007)).

These findings are specific, however, since, in contrast with many other countries, the US and Canada have very flexible labor markets. In a rigid labor market more persistent effects of a recession are expected. Employers then have more incentives to screen job applicants before hiring, because they are more forced into long-term relationships with their employees. If in an upturn screening is less costly among the pool of recent graduates than among a pool of jobseekers, unemployed because they graduated in a recession, then the latter group is more likely to be set back permanently. Genda et al. (2010) find supporting evidence of this hypothesis. In Japan the screening of recent graduates is indeed facilitated, both, because high schools are obliged by law to help firms in matching graduated students to jobs, and because social norm and resulting case law make dismissal of regular workers for economic reasons almost prohibitive. In contrast to their results for the US, these authors find strong and persistent

\footnotetext{
${ }^{4}$ Recently Hagedorn and Manovskii (2013) criticize this interpretation. They argue that wages are still determined by spot markets and not by long-term implicit contracts. They show that, once the current match quality is taken into account, past labor market conditions no longer play a role in the wage determination.

5 Kondo (2007) reports similar findings for other disadvantaged groups, such as black men and women. Hershbein (2012) pooling high school with college graduates reports findings lying in between of those found for low and high educated youth separately.
} 
(lasting more than 12 years) negative effects of a recession on both employment and earnings for low educated graduates in Japan. For the high educated, similar to the findings in the US, no significant effect on employment is found, while the effect on earnings also declines, but starts at a lower level and remains significantly negative after 12 years, rather than gradually fading away, as in the US. Recently, Kawaguchi and Murao (2014) find in a cross-country study more supporting evidence that recessions at labor market entry have more persistent adverse effects on the (un)employment rate ${ }^{6}$ in countries with more labor market rigidity as measured by EPL strictness, union coverage, and benefit duration of UI.7

Evidence from European studies only partially support the conclusions of aforementioned studies. Within countries with moderate to high labor market rigidity, such as Norway, Sweden, Austria, and Germany, persistent effects roughly in line with aforementioned theory are found. Raaum and Røed (2006) find that in Norway a business cycle slump at ages 16 and 19 raises prime age unemployment rates by as much as one to two percentage points. These authors do not study the effect on wages. More recently, Liu et al. (2012) report similar persistent negative effects on employment for college graduates. The effect of graduating in a period of high unemployment on earnings is only significantly negative during the first three years, but could be underestimated as a consequence of the positive selection induced by the effect on employment (Heckman, 1974). Kwon et al. (2010) study the effect of labor market entry conditions on wages of white collar workers in Sweden. If these workers enter the labor market in a boom they obtain faster promotions which leads to persistent wage premiums for such cohorts. Brunner and Kuhn (2014) report that in Austria a one percentage point increase in the unemployment rate decreases the daily wage by $0.9 \%$ and persists at least 20 years, but this is again a lower bound of the effect, since the employment rate is also persistently affected by the business cycle. Similar to high educated workers in the US, effects for white collar workers are smaller, and fade after five to ten years. However, in contrast to the US, and possibly related to labor market rigidity, blue collar workers suffer more importantly and more persistently from a recession. Stevens (2008) studying the effect for a population of low to medium skilled workers in Germany finds more persistent effects on employment and wages of a recession than for low educated workers in the US, but less persistent than in Austria and Japan for lower skilled workers. She reports a negative effect on employment during the first five years after graduation, which, as in the preceding study, leads to an underestimation of the effect on the wage in that period. The latter is important in the first four years after graduation, but fades away after seven years.

Two studies seem to contradict the theory that predicts more persistent effects in countries with strict labor market regulations. First, despite the high labor market rigidity in France,

\footnotetext{
${ }^{6}$ In contrast to our contribution, Kawaguchi and Murao (2014) do not consider effects on other labor market outcomes, such as on wages or earnings.

${ }^{7}$ Belgium was the most rigid country according to their composite index.
} 
Gaini et al. (2012) report in this country lower employment rates for cohorts graduating in a recession only during the first two years and no wage penalty. The authors advance two potential explanations: (1) a high minimum wage dampens the effect on wages and (2) a persistently high unemployment rate, such that employers use unemployment less as a negative signal in the hiring process (Biewen and Steffes, 2010; Kroft et al., 2013).

Second, according to Taylor (2013) leaving full-time education of any level in a recession in Britain, a country with relatively limited labor market protection, very negatively affects the probability of employment and the level of wages of young men, and this effect, even if it declines, remains very negative even after ten years of potential experience. The authors do not discuss why the effects are more important and persistent in Britain than in North-America, but part of the explanation could be related to having a more vocational based educational system in the Britain and a more a more general one in North-America. Hanushek et al. (2011) argue that, although vocational based education is beneficial for low educated at the start of the career by easing the transition into the labor market, their skills can very quickly become obsolete. Consequently, in case of a recession at graduation, the low educated may have more difficulties in integrating into the labor market once the economy recovers. By contrast, general education provides broad knowledge and basic skills that makes graduates more adaptable to changes in labor demand and, hence, less vulnerable to persistent damage in case of a temporary slowdown of economic activity. Nevertheless, this distinguishing feature of the educational system cannot explain why recessions in Britain lead to equally or even more persistent adverse labor market outcomes than in other European countries, since most other European countries share this more vocationally based educational system or have even developed it more, such as in Germany or Austria.

\section{Institutional Setting}

Belgium is a federal state which has decentralized territorial competences to three Regions (Flanders, Brussels and Wallonia) and person-related issues to three language Communities (Flemish/Dutch, French and German). Education is organized by the Communities, Unemployment Insurance (UI) and employment legislation by the federal authorities, and Active Labor Market Policies (ALMP) by the Regional employment offices. We briefly summarize the relevant institutional environment of the Flemish Region and Community for the period of analysis.

Since the beginning of the eighties education is compulsory up to age 18. At that age pupils have been six years in primary and six years in secondary school (high school). If they do not repeat a grade, they complete secondary education at that age, except for those in a vocational track for whom secondary education ends after seven years. Secondary school is segmented in implicitly hierarchical tracks: (i) general, (ii) technical, (iii) vocational, and a smaller arts track. In addition, from age 15, pupils may choose a part-time vocational or apprenticeship 
track. Downward reorientation and grade repetition is used more often as remediation policy than in other countries (OECD, 2012). The general and technical track directly (without a central entry exam) prepares for enrollment in higher education. Those in the vocational track must first complete a seventh specialization year. Our data refer to the pre-Bologna-reform period. At that time, three kinds of higher degrees could be obtained: (i) non-university of the short type (lasting three years), (ii) non-university of the long type, and (iii) university of the long-type (usually four or five years). According to the PISA studies assessing in a standardized way reading, mathematics and science skills at age 15 in large group of OECD countries, the Flemish pupils steadily performed at the very top of European countries. However, at the same time the spread of these scores is much higher than the OECD average, and the educational performance is highly segmented according to social background. School drop-out in secondary school is as high as 10\% (Cockx (2013a); http://www.pisa.ugent.be/en/en).

UI in Belgium is very generous, not so much in terms of level, but of length of the entitlement. It is one of the only countries in the OECD in which no time limit is set to the entitlement and in which school graduates are entitled to (flat rate) unemployment benefits (UB) if they are still unemployed nine months after registration. Job search requirements are very loose according to international standards, and non-participation to active labor market programs (ALMP) is hardly sanctioned (OECD, 2007; Cockx and Dejemeppe, 2012). Nevertheless, for youth UI may not be so large a disincentive for full-time work, since in Belgium the national minimum wage is among the highest in OECD (Cockx, 2013b). Moreover, in many sectors this national minimum is topped up, by $17 \%$ on average (Rycx and Kampelmann, 2013). Even if the minimum wage is found to have ambiguous effects on employment, at such high a level it is expected to reduce employment of low skilled youth, for whom it is most likely binding (Kramarz and Philippon, 2001; Neumark and Wascher, 2008; Cahuc and Carcillo, 2014).

Among the OECD countries, Belgium has close to the most stringent restrictions overall on individual and collective dismissals according to the OECD's EPL indicators (OECD, 2013). This is especially a consequence of very restrictive rules for collective dismissals. For individual dismissals in regular contracts EPL is less strict than the OECD average, but this conceals considerable heterogeneity in strictness according to the type of labor contract. In Belgium EPL for open-ended contracts differs between blue- and white-collar workers. For the latter group, it differs between those earning more than $€ 32,254$ a year and those earning less. The notice period for a blue-collar worker is generally less than one month for each five years of seniority, while for low-wage and high-wage white-collar workers it is three and five months respectively (Cockx, 2013b).

Even if EPL for blue collar workers is weak, a system of short-time work compensation (STC) specific for this group restrains firm mobility of blue collar workers. This STC compensates blue collar workers for temporary disruptions in business activity. These disruptions may last from 
maximum four weeks, in case of a complete temporary lay-off, up to maximum twelve months, in case of a work suspension of at most one week for every two weeks. Firms must justify the reason of the disruption to be able to invoke STC for their employees, but employer contributions financing the scheme are not experience rated. The replacement rate may reach nearly $100 \%$ (including employer top-ups), and no job search requirements or training are imposed on STC recipients, so that the scheme restrains mobility more strongly than in other countries. STC is extensively used in economic downturns and partly explains why the unemployment rate in Belgium only modestly increased during the Great Recession in 2008 (Hijzen and Venn, 2011; $\mathrm{H} \varnothing \mathrm{j}, 2013)$.

Finally, in a nutshell, in Belgium most of the wages are usually determined according to wage scales by function or level of education, and for white collar workers also by seniority or age. Wages are automatically adjusted to the evolution of the consumer price index, and every two years the trade unions and employers' organizations bargain at the sectoral level on the extent of real wage increase. Wages are therefore downward rigid (Fuss, 2009).

We mentioned in the Introduction that Belgium has one of the most rigid labor markets in OECD in that inflow rates into unemployment are among the lowest, while expected unemployment duration is among the highest. The description in this section suggests that this is very much a consequence of institutions. Nevertheless, the sources of this rigidity are very different for blue collar workers, than for white collar workers. This suggests that the mechanism underlying the long-run impact of adverse labor market conditions at graduation may be very different according to these two types of workers. Ideally, we would like to conduct a separate analysis for white and blue collar workers, but the choice between these worker categories is clearly endogenously related to the business cycle 8 Hence, we exploit two facts to rationalize a separate analysis for "low educated" (high school graduates or less) and "high educated" (above high school). First, the correspondence between low (high) education and being employed as a blue (white) collar worker is very high. $69 \%$ of the low educated are prevalently (i.e. more than $50 \%$ of the time) employed as blue collar workers, while for the high educated this figure is only 11\% (see Table S.9 in the Supplementary Online Appendix). Second, we provide evidence that the level of completed education is not endogenously related to the unemployment rate (see Section S.5 of the Supplementary Online Appendix).

\section{Data}

For this analysis it is important to be able to accurately determine the timing of graduation, since measurement error in this timing may lead to important compositional biases. For instance,

\footnotetext{
${ }^{8}$ The finding of Brunner and Kuhn (2014) that blue collar workers entering the labor force in an economic downturn are persistently locked in, low-paying jobs and/or tasks may potentially partly be a consequence of lower skilled workers being disproportionately hired as blue collar workers during adverse conditions.
} 
some studies assimilate graduation to the first registration as salaried worker according to administrative data. Such definition disregards those who transit from school to non-employment and, hence, disregards a group the size of which clearly varies with labor market conditions. This induces spurious correlation between labor market conditions at graduation and subsequent labor market outcomes.

To avoid this problem, we base our analysis on the Sonar surveys conducted on a representative sample of three birth cohorts, born in 1976, 1978 or 1980, and living in Flanders at age 23 , and which contains information on the time at which school is left.9 The surveys (as well as follow-up surveys at age 26 or 29) register retrospectively and on monthly basis the most important activity of the respondents, among which education. Based on this information, graduation is identified to occur in the first month that education has been interrupted for more than 4 months. This definition prevents considering summer breaks as exits from education 10 Individuals who re-enroll in education after the first exit (which corresponds to our definition of graduation) are included in the analysis and, hence, non-employed during this period. Reenrollment is, however, rare in Belgium. Only $3.6 \%$ of the final sample re-enroll at some point after the first graduation. We retain in the sample individuals leaving education between age 18, i.e. the compulsory schooling age in Belgium 11 and age 24. Graduates after age 24 are not considered, because the small number of individuals involved would complicate inference dramatically (see Section 5.2). The surveys also contain control variables for the analysis, which are measured at age 17, such that they are predetermined at graduation: father's and mother's education (years of completed education since age 12), the type of educational program (general, technical, vocational or a part-time vocational and apprenticeship program) in which the individual is enrolled at age 17 , and the number of grade repetitions at age 17 . The level of education is measured by the number of completed years of education: grade repetitions are not counted. This variable is used as a control in a sensitivity analysis.

The original Sonar sample contains about 3,000 individuals for each birth cohort, 9,000 in total. We only retain men to avoid dealing with sample selectivity induced by labor force withdrawal of women for reasons related to fertility and caring responsibilities. Apart from the aforementioned selection criteria regarding school-leaving age, we drop the following individuals to enhance sample homogeneity: those who attended special needs and arts education, who did not speak Dutch at home, or who did not permanently reside in Flanders at graduation. After eliminating, in addition, individuals with missing or inconsistent values in variables, this leaves us with a final sample of 3,514 men. A more detailed description of the variable construction and the sample selection can be found in Sections S.1 and S.2 of the Supplementary Online

\footnotetext{
${ }^{9}$ For more details, see $\operatorname{SONAR}(\sqrt{2004 \mathrm{a}} \cdot \sqrt{2003}, 2004 \mathrm{~b})$.

${ }^{10}$ In high school the summer break typically takes place in July and August, while in some colleges the break may already start in June and in universities it may stop only by the end of September.

${ }^{11}$ We drop $0.17 \%$ of individuals for which graduation is reported to occur before 18 .
} 
Appendix.

Our empirical analysis also hinges on having access to high quality information on labor market outcomes on a sufficiently long time span after graduation. We therefore matched the survey data to administrative data of Belgian Social Insurance institutions centralized at the Cross Roads Bank of Social Security. These data contain detailed quarterly information about labor market histories between 1998 and 2010 12 For salaried workers we construct the following outcomes: log annual earnings, log annual hours and log average hourly wage. The hourly wage is obtained by dividing annual earnings by the total number of hours worked in a year ${ }^{13} \mathrm{We}$ complement this information with three annual indicators of employment: self-employment (if registered as such part of the year, irrespectively of being a salaried worker in the same year), salaried employment (strictly positive earnings and not being self-employed), overall employment (either self- or salaried). Notice, by these very broad definitions of employment, the business cycle variation is more reflected in hours worked than in the employment rate. To get a sense of whether the variation in hours worked reflects fluctuations in the time spent unemployed or hours worked part-time 14 we also distinguish between hours worked full-time and part-time.

The administrative data provide additional control variables measured at age 17 (living in single parent household, not living together with either parents, the number of other household members by age class) and variables that help getting a better understanding of the mechanisms underlying the long-term negative impacts on individual outcomes of adverse labor market conditions at graduation (the median daily wage paid out on June 30 in recruiting firms and indicators of firm and provincial mobility $\sqrt{15}$. To obtain a measure of permanent firm quality, we average the log median wage within recruiting firms over the observation period in a similar way as Oreopoulos et al. (2012) (see Section S.1.3 of the Online Appendix for details).

Final sources of information are the Labor Force Surveys (LFS). These provide long time series of the provincial and nationa ${ }^{16}$ unemployment rates, used to characterize recessions in the labor market. Figure 1a plots both the youth (age 15-24) and overall unemployment rate (age

\footnotetext{
${ }^{12}$ Notice that part of the early labor market experience of cohorts graduating between 1994 and 1997 is missing.

${ }^{13}$ Taking log-transformations of these outcomes for salaried workers potentially leads to a sample selectivity problem, since for workers who are not in salaried employment this transformation is not defined and, hence, need to be dropped (Heckman, 1974). However, we will argue below that this selectivity is not a big concern in light of the evidence that graduating in downturns does not significantly affect the probability of being in salaried employment. Only for the high educated in the first few years after graduation there might be an issue, but this is discussed.

${ }^{14}$ The administrative data do not measure overtime for full-time workers, so this cannot be a source of variation in annual hours.

${ }^{15} \mathrm{An}$ individual is defined to change firm in year $t$ if he is observed in a different firm in at least two quarters of the year $t$, or if the first firm in which he was employed in year $t$ differs from the last firm in year $t-1$. Transitions between self-employment and salaried employment are included in the definition of firm mobility. An individual is defined to move in year $t$, if he lives in another province at the end of year $t$ than where he lived at the end of year $t-1$.

${ }^{16}$ National refers to "Flanders" and not to "Belgium".
} 
Figure 1: National and Provincial Unemployment Rates in Flanders.

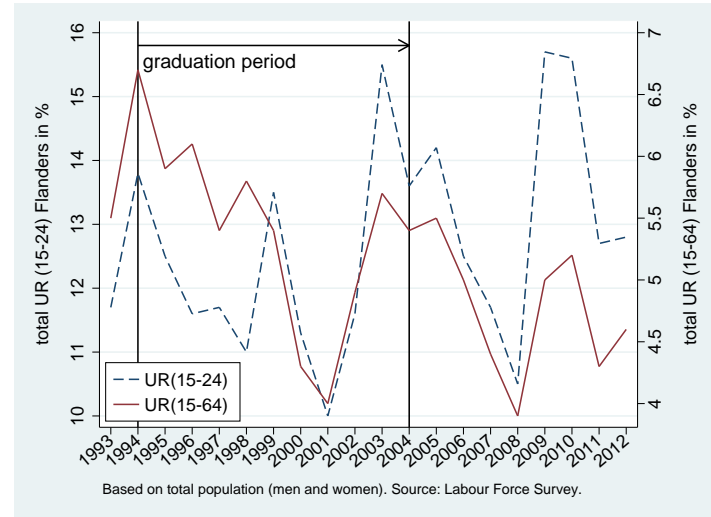

(a) National Unemployment Rates (UR): overall (age 15-64) and youth (age 15-24).

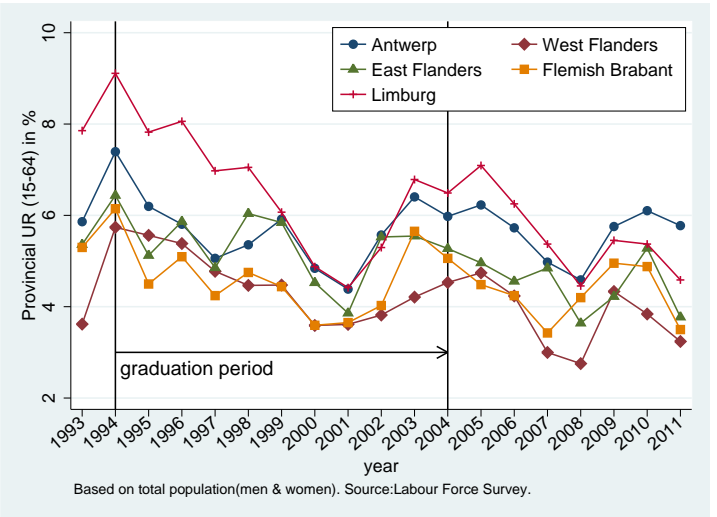

(b) Provincial Unemployment Rates (UR): overall (age 15-64).

15-64) from 1993 to 2012. Observe, even if the level and the variability of youth unemployment is much higher than the overall rate, the time pattern of both series is very similar. The period of graduation 1994-2004 covered by our data captures a complete cycle, so that the main effects of interest can be identified on national data. However, in line with the literature, we aim at exploiting provincial specific time-shocks in the analysis. As Flanders is a relatively small region, one may question whether commuting and changing residence would not make it impossible to exploit the latter variation. That is, workers could offset the negative impact of graduating in provinces with few job opportunities by moving or commuting to provinces with a tighter labor market. However, the magnitude of the inter-provincial variation in the unemployment rate reported in Figure $1 \mathrm{~b}$ demonstrates that mobility far from eliminates all inter-provincial variation 17

In Table A.1 in the Appendix A we report some descriptive statistics of the control variables in the retained sample. As mentioned at the end of previous section, we distinguish between men with a degree not higher than high school, i.e. "low educated", and those with a higher level of education, i.e. "high educated" as proxies for blue and white collar workers.

\section{Estimation Strategy}

To identify the long-term effects of labor market conditions at entry on the mentioned labor market outcomes, we exploit, separately for low and high educated youth, the variation in the unemployment rate at graduation both at the national and at the provincial level over 8 years (1994-2001 for the low educated and 1997-2004 for the high educated). We operationalize this

\footnotetext{
${ }^{17}$ Notice that unemployment is measured in the province of residence and not of job location. Hence if workers commute to avoid the negative local labor market conditions, this evens out the provincial variation in the unemployment rate.
} 
identification strategy by estimating, as in the existing literature (Section 2), a linear regression model of each outcome of interest on the unemployment rate at graduation and on a number of potentially confounding factors.

This identification strategy requires that the composition of the graduating cohort to be unrelated to this unemployment rate. We show that the unemployment rate at labor market entry is not significantly related to (i) the timing of graduation, and (ii) the province of living. As mentioned in the Introduction, we test the former by demonstrating that the duration between the end of compulsory education at the age of 18 and each year of potential graduation is unrelated to the provincial unemployment rate in those years ${ }^{18}$ In a nutshell, we estimate a proportional discrete hazard model (Kiefer, 1988; Jenkins, 1995$)$ that regresses a yearly indicator of graduation since age 17 on observed individual characteristics and the province of living measured at age 17, the elapsed duration (in years) in education since age 17, and the provincial unemployment rate in each potential year of graduation (i.e. an interaction term with the elapsed duration). We also accommodate for the potential sorting bias induced by unobserved (Gamma or Normal) heterogeneity. Since a joint test cannot reject that all aforementioned interaction terms are significantly different from zero (with p-values ranging from 0.42 to 0.95 ), we can safely conclude that the timing of graduation is exogenous to the business cycle. A detailed presentation and discussion of these tests can be found in Section S.5 of the Supplementary Online Appendix.

Since the provincial (national) unemployment rate is a serially correlated grouped regressor, it is well-known that standard inference is misleading in that it tends to over-reject null hypotheses (Bertrand et al., 2004). If, as in our case, the number of clusters is small (40 in the provincial model and 8 in the national model) ${ }^{19}$ it is very difficult to obtain correctly sized tests Angrist and Pischke, 2009; Cameron et al., 2008). In Section 5.2 we propose a new inference procedure that builds on the work of Brewer et al. (2013) and Wooldridge (2006, 2010), but that is modified to take the specificities of our data into account.

\footnotetext{
${ }^{18}$ In contrast, e.g. Kahn (2010) finds evidence that the timing of graduation is affected by the labour market conditions in her sample. Thanks to her, it is now standard to tackle this issue by instrumenting for the timing and the location of graduation with age and location of birth (or at some other young age). However, this approach does not work with our data, because contrary to the U.S., in Belgium grade repetition is widely used as remediation (see Section 3, so that age is not a good predictor of graduation, causing thereby a weak instrument problem.

${ }^{19}$ In the provincial model the number of clusters is equal to the 8 graduation years times the 5 provinces. The reader might argue that this number of clusters is not small. However, in line with expectations if it is, we find for continuous outcomes (not the discrete ones) that the standard cluster robust inference overestimates the precision of the estimators (see Section 6.3).
} 


\subsection{The Benchmark Linear Regression Model}

The most general benchmark provincial regression model, which is separately estimated for low and for high educated men, is specified as follows:

$$
y_{i g p t}=f_{g}(e) u_{g p}+f_{g u}(e) u_{g p} \mathbf{1}\left[u_{g p}<u_{(g-1) p}\right]+\theta_{e}+\phi_{t}+f_{t}(e) u_{p t}+\eta_{p}+\omega_{p} t+f_{0}(g)+x_{i}^{\prime} \delta+\varepsilon_{i g p t}
$$

where

- $y_{i t g p}$ is the labor market income of interest in calendar year $t$ for individual $i$ who graduated in year $g$ while living in province $p$ at the start of graduation year $g: 20$

- $u_{g p}$ is the unemployment rate in province $p$ and graduation year $g . f_{g}(e)$ is a linear spline in potential experience, so that the interaction with $u_{g p}$ represents the effects of interest, the long-run effects from graduating in downturns;

- $\mathbf{1}[$.$] denotes the indicator function which is one if the expression between brackets holds$ and zero otherwise, so that $\mathbf{1}\left[u_{g p}<u_{(g-1) p}\right]$ is equal to one in case of an upturn in the graduation year. $f_{g u}(e)$ is again a linear spline in potential experience. This second term estimates the long-run effects from graduating in upturns;

- $\theta_{e}$ is a fixed effect for potential experience $(e \equiv t-g), f_{0}(g)$ is a linear spline in graduation year and $\phi_{t}$ is a calendar year fixed effect, 21

- $u_{p t}$ is the unemployment rate in calendar year $t$ in the province $p$ in which the individual resides at the start of the graduation year $g$. This controls for provincial specific shocks in the unemployment rate not captured by $\phi_{t}$ and potentially correlated with $u_{g p}$. It is interacted with $f_{t}(e)$, a linear spline in potential experience, which allows the current unemployment rate to have different effects over time;

- $\eta_{p}$ is a fixed effect for the province of residence at graduation;

- $\omega_{p}$ is the provincial specific coefficient of a linear time trend. We include these provincial specific time trends, because the unemployment rates exhibit differential downward time trends (see Figure 1b);

- $x_{i}$ are individual control variables measured at age 17 reported in Table A.1.

\footnotetext{
${ }^{20}$ To avoid cumbersome notation, we ignore the subscript in $p_{g}$.

${ }^{21}$ Even after dropping the fixed effect of the reference category, calendar time effects cannot be separately identified from the effect of potential experience and graduation year, because of the accounting identity $e \equiv t-g$. Since the calendar time effect is not our main interest, we follow Oreopoulos et al. (2012) and ensure identification by just dropping a second calendar time fixed effect rather than imposing that the cohort effects sum to zero, as in Deaton (1997).
} 
- $\epsilon_{\text {igpt }}$ are the remaining errors, which include random unobserved province-graduation cohort effects and measurement errors that may be serially correlated (see Section 5.2).

The linear splines are expressed as follows:

$$
f_{m}\left(\tau_{m}\right)=\alpha_{m}+\sum_{j=0}^{J_{\tau_{m}}} \beta_{m j} .\left(\tau_{m}-3 j\right) \mathbf{1}\left[\tau_{m} \geq 3 j\right] \text { for } m \in\{g, g u, t, 0\}
$$

where, except for $m=g, \alpha_{m} \equiv 0, \tau_{m}=e$ if $m \in\{g, g u, t\}$, and $\tau_{0}=g . \beta_{m 0}$ is the slope of the linear function in potential experience (if $m \in\{g, g u, t\}$ ) or graduation year (if $m=0$ ), and $\beta_{m j}$ is the magnitude by which this slope changes every three years (i.e. if $\tau_{m} \geq 3 j$ ). The slope may change at most $J_{\tau_{m}}$ times. $J_{e}=3$, but for the high educated sample we set $\beta_{m 3}=0$ for $m \in\{g, g u, t\}$, since at most 10 years of potential experience are considered instead of 12 years for the low educated ${ }^{22} J_{g}=2$, since only 8 graduation years are considered.

$f_{g}(e)$ is the function of interest, since it describes for each year $e$ since graduation the effect of a percentage point increase of the unemployment rate at graduation on the outcome of interest. We allow for an asymmetric effect in an upturn which, similarly, is measured by a percentage point decrease of the unemployment rate at graduation. ${ }^{23}$ The effect of a percentage point decrease of $u_{g p}$ is $-\left(f_{g}(e)+f_{g u}(e)\right)$. $f_{t}(e)$ allows for a differential effect of the current provincial unemployment rate from the common calendar year effect $\phi_{t} . f_{0}(g)$ controls for common graduation year effects.

For all outcomes we always start by estimating the most general specification as specified in (1) ${ }^{24}$ However, to enhance precision, we check each time whether we can impose the following restrictions: all splines for the upturn and the current unemployment rate $u_{p t}$ jointly equal to zero; all $\theta_{e}$ and $\phi_{t}$ replaced by a linear spline as defined in (2); all $\omega_{p}$ jointly equal to zero. In Section 6 we only report the results of the estimations in which restrictions are imposed that could not jointly be rejected at the $5 \%$ level. We report in the tables which restrictions are imposed.

Finally, in a sensitivity analysis we also estimate a model in which we exploit the time variation of the national unemployment rate. In this national model the subscripts $p$ disappear and also $f_{t}(e) u_{p t}, \eta_{p}$ and $\omega_{p} t$, since these terms are then no longer identified.

\footnotetext{
${ }^{22}$ We restrict the number of graduation and experience years in the analysis to avoid too small cell sizes, as this is problematic for inference (See Section 5.2). Beyond 10 (12) years of experience not all birth cohorts of the high (low) educated are observed any longer.

${ }^{23}$ This specification has been proposed by Genda et al. (2010).

${ }^{24} \mathrm{Eq} .11$ is our preferred specification as it controls for a large set of confounding factors discussed in the literature. Our findings are, however, robust to a more parsimonious specification in which we do not allow for asymmetric effects during upturns $\left(f_{g u}(e)=0\right)$ and for contemporaneous economic conditions to vary with experience $\left(f_{t}(e)=0\right)$. The results of this sensitivity analysis can be found in Section S.10 of the Supplementary Online Appendix.
} 


\subsection{Inference with a Small Number of Clusters}

If there are a small number of clusters, Cameron et al. (2008) and Cameron and Miller (2015) propose using the wild bootstrap to obtain correctly sized tests and confidence intervals. The method is, however, not so trivial to implement and, as acknowledged by the authors, computationally intensive for forming confidence intervals ${ }^{25}$ Moreover, the method does not exploit the possibility of enhancing the power of the statistical tests. Brewer et al. (2013) recently proposed a straightforward method for inference that addresses these limitations in a differencein-differences (DiD) design. They demonstrate in Monte Carlo analysis that correctly sized tests can be obtained by using bias corrected clustered standard errors in an ordinary least squares (OLS) regression of the covariate-adjusted group-time means of the dependent variable on the covariates varying at the group-time level. The bias correction is simple to implement, because STATA correctly scales the standard errors by default. To enhance the power of this approach, the authors exploit the serial correlation in the grouped errors using the feasible generalized least squares (FGLS) estimator proposed by Hansen (2007) ${ }^{26}$ that explicitly allows for a common autocorrelation pattern (e.g. AR(2)) across groups. To allow for misspecification of this autocorrelation process the aforementioned cluster robust inference is applied to this FGLS estimator. This delivers, as the wild bootstrap, correctly sized tests and, if the number of time periods is sufficiently large (from about 10 time periods), yields substantial power gains.

Since our model can be seen as a generalized DiD setting, in which we have variables that vary at the group level $(g p)$, i.e. each combination of graduation year $(g)$ and province $(p)$ is a cluster, at the time level $(t=g+e)$, and at the group-time level $(g p t)$, this approach can be applied to our analysis. However, in contrast to Brewer et al. (2013), group-time cells in our sample contain a relatively small number of observations, so that we cannot ignore measurement error in the covariate-adjusted group-time means of the dependent variables. To generalize their approach, we build on the work of Wooldridge (2006, 2010). Wooldridge proposes a FGLS estimator in case of cross-sectional data with only measurement error and no unobserved group effects. We adjust this method for panel data and show how, as in Brewer et al. (2013), autocorrelated unobserved group effects can be integrated in this approach.

In a first step, run a regression of $y_{i g p t}$ on $x_{i}$ and group-time dummies using the micro-data on the individual level:

$$
y_{\text {igpt }}=\mu_{g p t}+x_{i}^{\prime} \delta+\epsilon_{\text {igpt }}
$$

\footnotetext{
${ }^{25}$ We aim at identifying the effect of increasing the unemployment rate at graduation by one percentage point for each of the up to 12 years after graduation. This requires forming confidence intervals of the values of the linear spline defined in Equation (2) for each year after graduation. These values involve linear combinations of the parameter estimates. Apart from further intensifying the computational burden, it is not obvious how to proceed in this case.

${ }^{26}$ Brewer et al. (2013) show that Hansen's bias-corrected FGLS delivers only little more power than the ordinary FGLS.
} 
where $\mu_{g p t}$ are the group-time fixed effects, i.e. the covariate-adjusted group-time means, and $\epsilon_{\text {igpt }}$ is the error term of this micro regression. In a second step, the estimated group-time fixed effects $\hat{\mu}_{g p t}$ are regressed on the group-time level covariates:

$$
\hat{\mu}_{g p t}=f_{g}(e) u_{g p}+f_{g u}(e) u_{g p} \mathbf{1}\left[u_{g p}<u_{(g-1) p}\right]+\theta_{e}+\phi_{t}+f_{t}(e) u_{p t}+\eta_{p}+\omega_{p} t+f_{0}(g)+v_{g p t}
$$

where $v_{g p t}=e_{g p t}+\left(\hat{\mu}_{g p t}-\mu_{g p t}\right), e_{g p t}$ is the unobserved group-time shock measured at calendar time $t$ and $\left(\hat{\mu}_{g p t}-\mu_{g p t}\right)$ is the measurement error in the covariate-adjusted group-time means. Brewer et al. (2013) assume the latter to be zero. Consequently, even if cluster robust standard errors still result in correct inference, taking the (co-)variances of the measurement errors into account could enhance efficiency.

In the case of cross-sectional data, Wooldridge (2006, 2010) proposes implementing the efficient Minimum Distance (MD) estimator, also called the 'Minimum Chi-Square' estimator, of the covariate-adjusted group means on the group level explanatory variables. This consists in estimating (a cross-sectional) version of (4) by FGLS. If $e_{g p t}=0$, the optimal weight in the FGLS is the inverse of the variance matrix of $\left(\hat{\mu}_{g p t}-\mu_{g p t}\right)$ estimated in the first step. Since the efficiency of this procedure depends on whether unobserved group-time shocks $e_{g p t}$ are indeed zero, it is useful to notice that this can be tested for. If the observed group level explanatory variables cannot fully explain the variation in $\hat{\mu}_{g p t}$, the regression model (4) is likely to be rejected against the saturated model, i.e. the weighted sum of squared residuals (WSSR), distributed $\chi^{2}$ with degrees of freedom equal to the number of groups minus the number of estimated parameters, is larger than the conventional rejection level.

Generalizing Wooldridge (2006, 2010)'s approach to panel data requires accounting for the serial correlation in the error term $\epsilon_{i g p t}$ of the first step regression. We do this by taking the individual $i$ as clustering unit in the first step and use the conventional cluster-robust variance matrix of the $\hat{\mu}_{g p t}$ estimated in the first step as weighting matrix in the second step ${ }^{27}$ The $\chi^{2}$ goodness-of-fit statistic allows testing for the presence of unobserved group-time shocks, i.e. $e_{\text {gpt }} \neq 0$. In case of no rejection, the conventional standard errors can be used for inference. In case of rejection, ${ }^{28}$ the (bias-corrected) cluster robust standard errors allow for serial correlation in $e_{g p t}$.

In case of rejection, we attempt to increase power by explicitly allowing for the variance in $e_{\text {gpt }}$ in addition to that of the measurement error, and for a particular serial correlation pattern in $e_{g p t}$, as in Brewer et al. (2013). To this purpose, we follow Amemiya and Nold (1975) by assuming that the measurement errors $\left(\hat{\mu}_{g p t}-\mu_{g p t}\right)$ and the unobserved group-time shocks $\left(e_{g p t}\right)$ are uncorrelated, and that the variance of $e_{g p t}$ is homoskedastic across groups and time, so that we can estimate the latter by subtracting an estimate of the average variance of the measurement

\footnotetext{
${ }^{27}$ Since the individual is taken as clustering unit, the number of clusters is sufficiently large to implement conventional inference procedures.

${ }^{28}$ We use the conventional $5 \%$ as threshold for the size of the test.
} 
error $\left(\widehat{\operatorname{var}}\left(\hat{\mu}_{g p t}\right) \equiv \hat{s}_{g p t}^{2}\right)$ from an estimate of the average variance of the composite error term $v_{g p t}$ :

$$
\widehat{\operatorname{var}}\left(e_{g p t}\right) \equiv \hat{\sigma}_{e}^{2}=\frac{1}{G P T} \sum_{g=1}^{G} \sum_{p=1}^{P} \sum_{t=1}^{T}\left(\hat{v}_{g p t}^{2}-\hat{s}_{g p t}^{2}\right)
$$

where $\hat{v}_{\text {gpt }}$ denotes the residual of an OLS regression of (4), G the number of graduation years, $\mathrm{P}$ the number of provinces, and $\mathrm{T}$ the number of calendar years retained in the grouped regression 29 Subsequently, this estimated variance can be added to the diagonal of the variance matrix of the measurement error to obtain an estimate of the (heteroskedastic) variance matrix of $v_{g p t}: \widehat{\operatorname{var}}\left(v_{g p t}\right)=\hat{\sigma}_{e}^{2}+\hat{s}_{g p t}^{2}$. The inverse of this variance is then used to estimate the parameters in (4) by FGLS ${ }^{30}$ Depending on whether the $\chi^{2}$ goodness-of-fit statistic rejects the model or not, respectively conventional or cluster robust standard errors should be calculated after this modified FGLS.

In this empirical application we find for most outcomes that $\hat{\sigma}_{e}^{2}<031$ even if the aforementioned $\chi^{2}$ rejects the model and, hence, suggests that unobserved group-time shocks are present. This suggests that the imposed homoskedasticity assumption is not satisfied, and that it is thus difficult to enhance power by explicitly taking the unobserved group-time shocks, in addition to the measurement error, into account. The cluster robust standard errors calculated after the FGLS that just takes measurement error into account still provides correct inference, however. These are therefore the ones that we report in most of our estimations when the goodness-of-fit statistic rejects the model.

Finally, we explain how we deal with a number of practical issues encountered with the proposed inference methods. First, the benchmark outcomes must satisfy adding-up constraints: (i) the indicator of salaried employment and the one of self-employment sum to the indicator of overall employment; (ii) log hourly wages and log annual hours worked sum to log annual earnings; (iii) the sum of the annual number of hours worked full-time and part-time is equal to the total annual hours worked. These adding-up constraints are automatically satisfied if the first and second step regression models, (3) and (4), are estimated by OLS. However, this is no longer true if FGLS is applied in the second step on each outcome separately, since then the weighting matrices ignore the correlation that these constraints impose on these outcomes. To overcome this problem, we jointly estimate both the first and the second step in a seemingly unrelated regression (SUR), as proposed by Zellner (1962). Since the adding-up constraint makes the variance matrix of the three outcomes singular and hence non-invertible, we leave out one of the three outcomes and calculate the parameters and standard errors of the third model from

\footnotetext{
${ }^{29}$ In the data the number of calender years varies by group, i.e. by $g p$ combination. Therefore $T$ should be indexed by $g p$, but to avoid cumbersome notation we do not do this.

30 Cockx and Dejemeppe (2005) show how an AR(1) process on $e_{\text {gpt }}$ can be modeled.

${ }^{31}$ We only find $\hat{\sigma}_{e}^{2}>0$ for salaried employment rate in the national model, both the low and high educated group (see Section S.9 of the Supplementary Online Appendix).
} 
the constraint 32 An estimate of the variance matrix, the inverse of which is used as weight in the second step FGLS SUR, is obtained from the conventional cluster robust estimate of the variance matrix of the covariate adjusted means $\hat{\mu}_{g p t}$ calculated after a pooled OLS on the first step SUR. By clustering at the individual level in the first step, the variance matrix accounts not only for unrestricted serial correlation in the outcomes, but also for unrestricted correlation across outcomes.

Second, in our data we find cases in which the employment status of all individuals belonging to a cluster $g p$ does not vary over some calendar years $t$. This induces perfect serial correlation in the covariate-adjusted group-time means $\mu_{g p t}$ and, hence, the cluster robust variance matrix of these $\hat{\mu}_{g p t}$ is singular. We therefore use in these cases the Moore-Penrose generalized inverse of the variance matrix as weight in the second step FGLS. To avoid numerical imprecision, we manually set as many eigenvalues to zero as the number of times that the employment rate for particular groups is repeated over time. This accordingly reduces the number of degrees of freedom in the second step.

Finally, asymptotic inference for the Minimum Chi-Square estimator is only valid if groups are sufficiently large. In the statistical literature some rules of thumb are suggested for what is large enough for the Central Limit Theorem to apply. For continuous outcome variables (such as log hours, log wages or log earnings) a group size $\left(N_{g p t}\right)$ of 30 observations is typically considered sufficient, while for dichotomous outcomes (such as the employment rate) the minimum of the expected number of successes and failures should be sufficiently large. A commonly accepted rule for the latter is that $\min \left\{N_{g p t} P_{g p t}, N_{g p t}\left(1-P_{g p t}\right)\right\} \geq 5$, where $P_{g p t}$ denotes the probability of success and which can be estimated by aggregating the individual predictions of this probability in the first step OLS regression of (3) to the cluster-time level gpt. According to Cochran (1954) the approximation is, however, still acceptable if for less than $20 \%$ of the groups this expectation is smaller than 5 while remaining larger than 1.

For the national model these rules are satisfied if we restrict the analysis to graduation years 1994-2001 for the low educated and to 1997-2004 for the high educated. For the provincial model we must drop additional groups. For the continuous outcomes, applying the aforementioned rule reduces the sample size too much, so that we retain groups-time cells containing between 16 and 30 observations, which still delivers a reasonable approximation if the distribution of the underlying random variable does not differ too much from the Normal. For the dichotomous outcomes, we calculate for each group-time cell and outcome the aforementioned expectations, take the minimum of these expectations over the outcomes retained in the same SUR, and drop group-time cells with the smallest minimum until the aforementioned Cochran's rule is satisfied.

Dropping these cells introduces, however, a concern of selectivity. We therefore test for this.

\footnotetext{
${ }^{32}$ Barten (1969) has shown that the parameter estimates are invariant to the equation deleted. However, Berndt and Savin (1975) have demonstrated that in case a model with autoregressive disturbances is modeled invariance requires restrictions on the parameters of the autoregressive process.
} 
We construct for each outcome an indicator that is equal to one if the individual belongs to a group-time cell that is dropped according to the aforementioned rules and zero otherwise. Subsequently, we use these indicators as dependent variable in a one-step regression on model (1) in which we impose the same restrictions as the ones used for the corresponding outcome, and in which we cluster the standard errors by group gp. Finally, we test the null hypothesis that all the coefficients of the linear spline $\left(f_{g}(e)\right)$ that interacts the unemployment at graduation $\left(u_{g p}\right)$ are jointly significantly different from zero. Since the number of clusters is small, we tend to over-reject the null-hypothesis. But the null hypothesis is never rejected in any of the considered outcomes, so that we can therefore be confident that selectivity is not an issue.

In Table A.2 in Appendix A we report for the benchmark continuous and dichotomous outcomes the number of cells that are dropped and retained, as well as the mean and maximum size of these cells. We also provide the aforementioned statistics for cells that are retained, but that do not satisfy the aforementioned stricter rules, i.e. for cell sizes between 16 and 30 if the outcome is continuous, and for cells for which the minimum of the aforementioned expectation is smaller than 5 in case of a dichotomous outcome. Finally, we also include the P-value of the joint test of selectivity mentioned in the previous paragraph.

\section{Results}

We now discuss our findings for the low educated and high educated sub-samples. We will report for each outcome the effect of a percentage point $(p p)$ increase in the unemployment rate by the potential number of years of experience in the labor market since graduation. This corresponds to what is commonly reported in studies, but notice that it is difficult to use these effects to make cross-country comparisons. This is because a $p p$ rise of the unemployment rate in a typical recession depends on the degree of labor market flexibility, and also on whether the overall, or youth unemployment rate is used in the analysis. In a rigid labor market the unemployment rate varies less over the business cycle, than in a flexible one, and the youth unemployment rate tends to vary more than the overall rate. The problem is that studies usually do not report by how many $p p$ 's the unemployment rate increases in a typical recession. An exception is the study of Oreopoulos et al. (2012) for Canada, characterized by a flexible labor market. The authors report that the unemployment rate rises by five $p p$ 's in a typical recession. To compare, in Flanders this figure was only 1.4 pp's on average in the 1994-2010 period (and by 1.6 point only in the Great Recession in 2008) 33 Consequently, if we want to compare the effect of a typical recession in Canada to such one in Flanders, we must multiply the effect of a $p p$ increase of the unemployment rate in Canada by a much larger factor than in Flanders. This can put

\footnotetext{
${ }^{33} \mathrm{~A}$ recession is defined to be a period during which the unemployment rate increases uninterruptedly. Hereafter, we will refer to a "typical recession" as the average $p p$ increase of the provincial unemployment rate during such recessions in Flanders in the 1994-2010 period.
} 
the findings in a different perspective. For instance, despite the short-term effect of a one $p p$ increase of the unemployment rate on earnings is much smaller for high educated Canadian graduates $(-1.8 \%)$ than for Flemish $(-5.8 \%)$, the effect for a typical recession is comparable or even slightly larger in Canada ( $-9 \%$ versus $-8.1 \%)$.

\subsection{The Findings for the Low Educated}

In Figure 2 we graphically report for the low educated sample the effect of increasing the provincial unemployment rate at graduation by one $p p$ on the main outcomes of interest. The reader can find in Table B.1 in Appendix B the corresponding point estimates and standard errors, as well some information about the estimated model, among which the P-value of the goodnessof-fit statistic, whether cluster-robust or conventional standard errors are used (conventional standard errors are used if the aforementioned $\mathrm{P}$-value exceeds 5\%), and which restrictions were imposed on the benchmark specification (4). The complete estimation results (including the first step (3) and the second step OLS) are only reported in Section S.6 of the Supplementary Online Appendix. Notice that for all provincial models (4) was estimated in a SUR by FGLS in which the estimated variance of the unobserved group effects was set to zero $\left(\widehat{v a r}\left(e_{g p t}\right)=0\right)$, since in all cases it was estimated to be strictly negative in (5). It is actually only found to be strictly positive for one outcome only in case that the variation of the national unemployment rate was exploited (see Section S.9 of the Supplementary Online Appendix).

The top panel of Figure 2 reveals that a recession at graduation does not significantly (at $5 \%$ ) affect employment, but confidence intervals are relatively wide, especially for salaried and self-employment. The point estimate suggests that a one $p p$ increase of the unemployment rate at graduation increases the self-employment rate by 3.6 pp's (significant at 10\%), but this effect rapidly drops to zero after three years. This provides weak support that a recession pushes young low skilled graduates to self-employment by lack of salaried employment 34 It also suggests that there might be some pressure from employers in economic downturns to takeup pseudo self-employment, as avoid the minimum wage restrictions and to be able to pay lower Social Insurance contributions that are due for self-employed workers (see e.g. European Commission (2010) ). In line with this evidence, the salaried employment rate decreases, but to a lesser extent: according to the point estimates, -1.7 and $-1.1 p p$ in the first and second year of potential experience, but these estimates are not significant. Since the point estimate of the effect on salaried employment is very close to zero beyond the first two years of potential experience, we should only be concerned that the effect of the unemployment rate at graduation on variables that are solely observed in case of salaried employment, such as wages, hours and

\footnotetext{
${ }^{34}$ There are two competing hypotheses on the role of the business cycle on self-employment. Aside the mentioned push hypothesis, the pull hypothesis states that high unemployment negatively affects individual expectations about the success of self-employment, or reinforce credit constraints. Empirical evidence on the relative importance of these hypotheses is mixed. For recent evidence, see e.g. Fairlie (2013) and Yu et al. (2014).
} 
earnings, is biased as a consequence of selectivity (Heckman, 1974) in the first few years after graduation, if at all.

In the middle panel of Figure 2 we observe that the average hourly wage is hardly affected by adverse conditions at graduation. At the same time the annual number of hours worked drops persistently during the 12 first years of potential experience, starting from a decrease of $4.4 p p$ in the first year after graduation, increasing slightly to a value that ranges between -2.5 and -3 $p p$ from year three to twelve. From the bottom panel we can deduce that nearly all the effect on hours worked is induced by a reduction in hours worked full-time, and not by an increase in hours worked part-time. Only in the first year after a recession, the number of hours worked part-time increases significantly. These findings are in line with the hypothesis that the minimum wage is binding for this low skilled youth and, hence, induces a higher incidence of unemployment ${ }^{35}$ They are also in accordance with the literature, mentioned in the Introduction, that early career unemployment permanently increases the likelihood of unemployment later in the career (e.g. Schmillen and Umkehrer (2013)). However, they contrasts starkly with the sharp temporary downward adjustment in wages, and marginal effects on employment and hours that Genda et al. (2010) report for low educated youth in the flexible US labor market.

The effect on earnings nearly mirrors that on hours worked. This is because the effect on wages is close to zero. We also find that the effect of an upturn at graduation on hours worked is not symmetric to that of a downturn. In an upturn the number of hours increase more importantly than they decrease in a downturn. Up to four years after an upturn, the hours worked increase by 5 to $6 \%$ for each $p p$ decrease of the unemployment rate at graduation. Thereafter the effect gradually fades to zero after ten years. This means that the costs of a recession are lower than the benefits of a boom, but also that the costs are more persistent.

Even if the wage is hardly affected by the business cycle at graduation, we find that an increase of one $p p$ of the unemployment rate at graduation persistently decreases the median wage in the recruiting firms by roughly $1.5 \%$ over all 12 years following labor market entry and this effect is always significant, or close to (see Table B.2. This suggests that scars of a recession are not only induced by a higher incidence of unemployment, but also by the lower quality of the first job, which is not directly apparent, because of the downward rigidity imposed by the minimum wage. This is in line with the observation in the middle panel of Figure 2 that some years after labor market entry a recession at graduation does seem to have a growing negative impact on the hourly wage. In the benchmark model this growing negative impact is not statistically significant. However, when in the sensitivity analysis we consider the second step OLS instead of FGLS estimates this impact steadily decreases and becomes significantly negative at the $5 \%$ level beyond seven years of experience (see Table S.21 of the Supplementary Online Appendix). This is compatible with the hypothesis that lower quality jobs entered during

\footnotetext{
${ }^{35}$ This is not incompatible with a zero effect on the employment rate, because the latter is only affected if the unemployment spell is not interrupted by any employment throughout a complete calendar year.
} 
Figure 2: The Effect of a One Percentage Point $(p p)$ Increase in the Provincial Unemployment Rate at Graduation: Low Educated
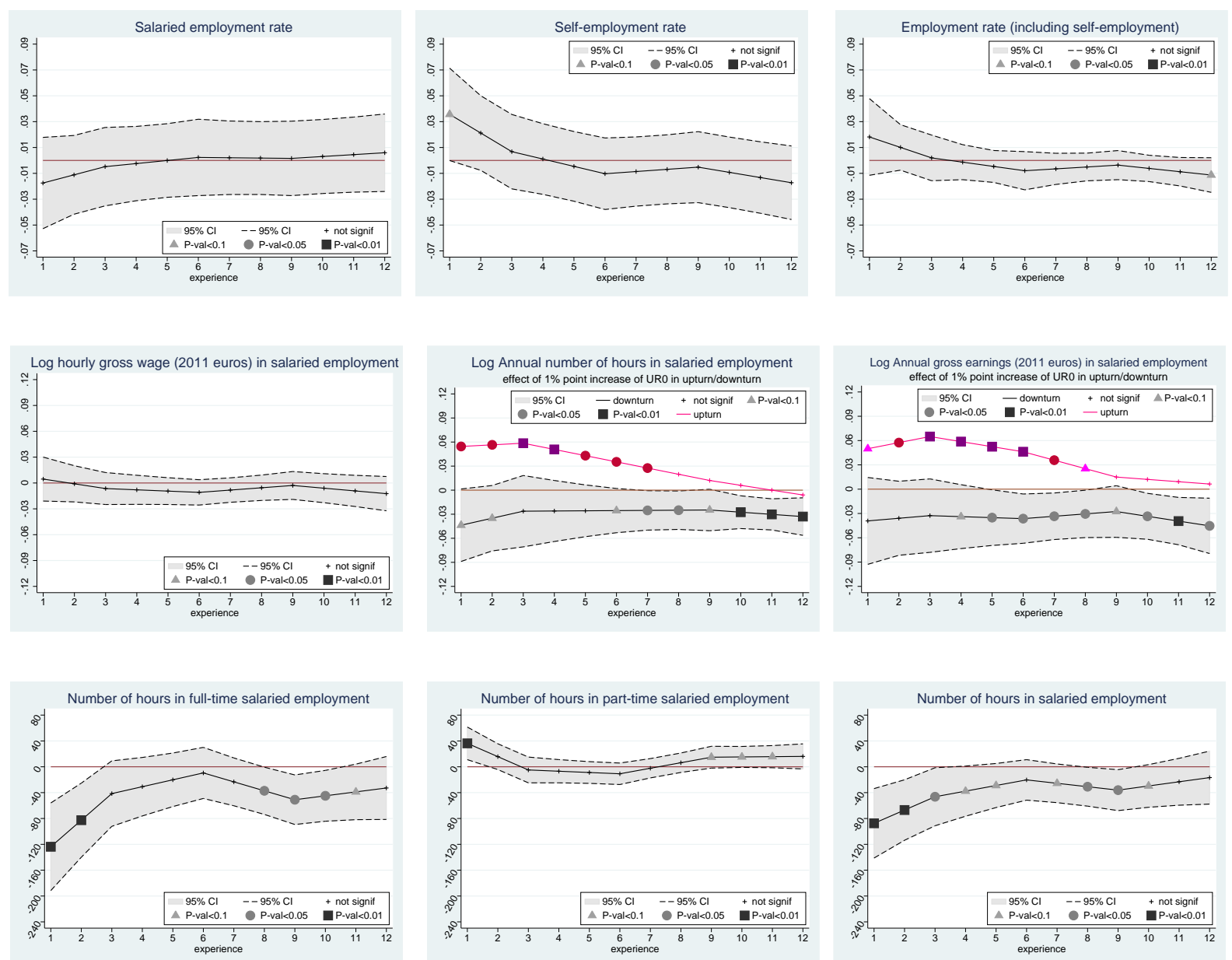

The figure displays for the low educated the effect of increasing (decreasing in case of an upturn) the provincial unemployment rate at graduation by one $p p$ on the main outcomes of interest. The effects reported in top, middle and bottom panel result each time from two-step FGLS estimates of a SUR model on the first two outcomes described in detail in Section 5.2 The effects for the third outcome are obtained from the following adding up constraints: salaried employment+self-employment=overall employment; log hourly wage+log hours worked=log earnings; FT hours worked+PT hours worked=total hours worked. Table B.1 in Appendix B reports the corresponding point estimates displayed in the figure. 
a recession have a less steep wage profile with seniority than the higher quality jobs accessed during a tight labor market.

Since EPL is much stricter for white collar than for blue collar workers (see Section 3) and the high educated are predominantly employed as white collars and the low educated as blue collars (see Section 4), firm mobility is expected to be higher for the low than for the high educated. This is only to a minor extent reflected in the fraction that remains employed in the same firm. Five (ten) years after graduation this fraction is $26 \%$ (15\%) for the low educated and $31 \%(17 \%)$ for the high educated 36 This may be a consequence of the system of STC, which allows firms to retain blue collar workers over the business cycle (see Section 3). By contrast, $24 \%(18 \%)$ of the low educated changes jobs in more than two (four) out of the first (ten) years of potential experience against $12 \%$ (7\%) of the high educated. This suggests that a lower EPL strictness does not so much enable more upward mobility, but that it rather leads to a more pronounced segmentation of the labor market in, on the one hand, a segment with relatively stable employment and, on the other hand, a segment in which workers cycle from one short tenured job to another. But this relationship is not necessarily causal, since this type of segmentation can be a characteristic of the labor market for low skilled workers. In any case, the less strict EPL does not allow the unfortunate low educated, entering the labor market during a recession, to catch up with the more fortunate group. The unemployment rate at graduation is unrelated to firm mobility (see Table B.2. ${ }^{37}$

Finally, geographic mobility is negligible. During the observation period each year on average only $1.5 \%$ of the low educated changes residence to another province. It is therefore not surprising to find that the unemployment rate at graduation is unrelated to geographic mobility (see Table B.2).

\subsection{The Findings for the High Educated}

The findings for the high educated can be found in Figure 3 and Table C.1. In the top panel of Figure 3 we see that the overall employment rate of the unfortunate cohorts is during the first five years after graduation slightly, but significantly lower than that of the more fortunate cohorts. The point estimates gradually rise from $-1.5 p p$ to zero in these years. After five years the effects remains very closely to zero. In view of the wide confidence intervals, it is difficult to assign this negative impact to a decrease in salaried or self-employment. According to the point estimates, the drop in the first year is completely explained by the lower salaried employment rate, while in the subsequent years it seems that the lower self-employment rate is more the driving force. In any case, the impact on the employment rate is relatively small, which is to be expected, because higher educated are more in demand, irrespectively of the business cycle. Hence, also

\footnotetext{
${ }^{36}$ For more detailed statistics, see the Supplementary Online Appendix Table S.12.

${ }^{37}$ The unemployment rate at graduation is also unrelated to sector mobility. Results are available upon request.
} 
the aforementioned selectivity issue for the labor market outcomes in salaried employment is likely to be negligible, or matters at most during the first two years after graduation. In contrast to our findings for the low educated, a recession does have a significant negative impact on the hourly wage. In the first two years it is slightly lower than in the following ones, but this could be a consequence of the aforementioned selectivity problem. Those who are unemployed in the first years after a recession are likely to be less productive and earning lower wages than the group that is employed in these years. This may bias the negative effect on wages slightly upwards. From the third year this bias should no longer play a role. We observe that the wage penalty rises steadily (and significantly) from then onwards, starting at $-3.2 \%$ after three years and attaining $-4.4 \%$ after ten years. The initial wage penalty suggests that high educated graduates are forced to accept lower quality jobs for which they are possibly overeducated (see Baert et al. (2013) for evidence on this using the same survey data) and which pay lower wages. As a consequence of the high labor market rigidity, in particular the strict EPL (see Section 3), job mobility is limited (see more evidence of this below). Hence, these unlucky generations are trapped in these lower quality jobs and definitely miss the opportunity to be hired in career jobs with a steeper seniority pay profile. In line with this hypothesis, the aforementioned study of Baert et al. (2013) demonstrates that young unemployed graduates who accept a job for which they are overeducated remain trapped in these jobs for many years. This explains why the wage penalty rises over time rather than gradually fades, as in more flexible labor markets (Genda et al., 2010, Oreopoulos et al., 2012).

The annual number of hours worked is $3.5 \%$ lower for each $p p$ rise in the unemployment rate at graduation, but rapidly rises to zero after three years, level at which it remains subsequently. From the bottom panel of Figure 3 we can deduce that this is nearly entirely ${ }^{38}$ due to a reduction in full-time hours. This suggests that those who refuse to downgrade become temporarily unemployed. But in contrast to lower educated workers, this does not permanently increase the likelihood of unemployment later in the career, but rather raises the likelihood of remaining employed in lower quality jobs.

The combined effect on wages and hours yields the effect on earnings. At the start of Section 6. we have already made a comparison of this effect with that of the more flexible labor market in Canada. Notice also, that the effect on hours worked is, as for the low educated, asymmetric for up- and downturn. In an upturn the annual number of hours worked increases slightly more and slightly longer.

In the previous section we already described firm mobility, and explained that the strict EPL for white collar workers lowers it for the high relative to low educated. Nevertheless, in contrast to the low skilled, we do find some evidence (see Table C.2 in Appendix C) that the high skilled who graduate during a downturn are more likely to move from one job to another

\footnotetext{
${ }^{38}$ We also observe a small, but permanent increase in the number of hours worked part-time.
} 
Figure 3: Effect of one $p p$ Increase in the Provincial URate at Graduation: High Educated
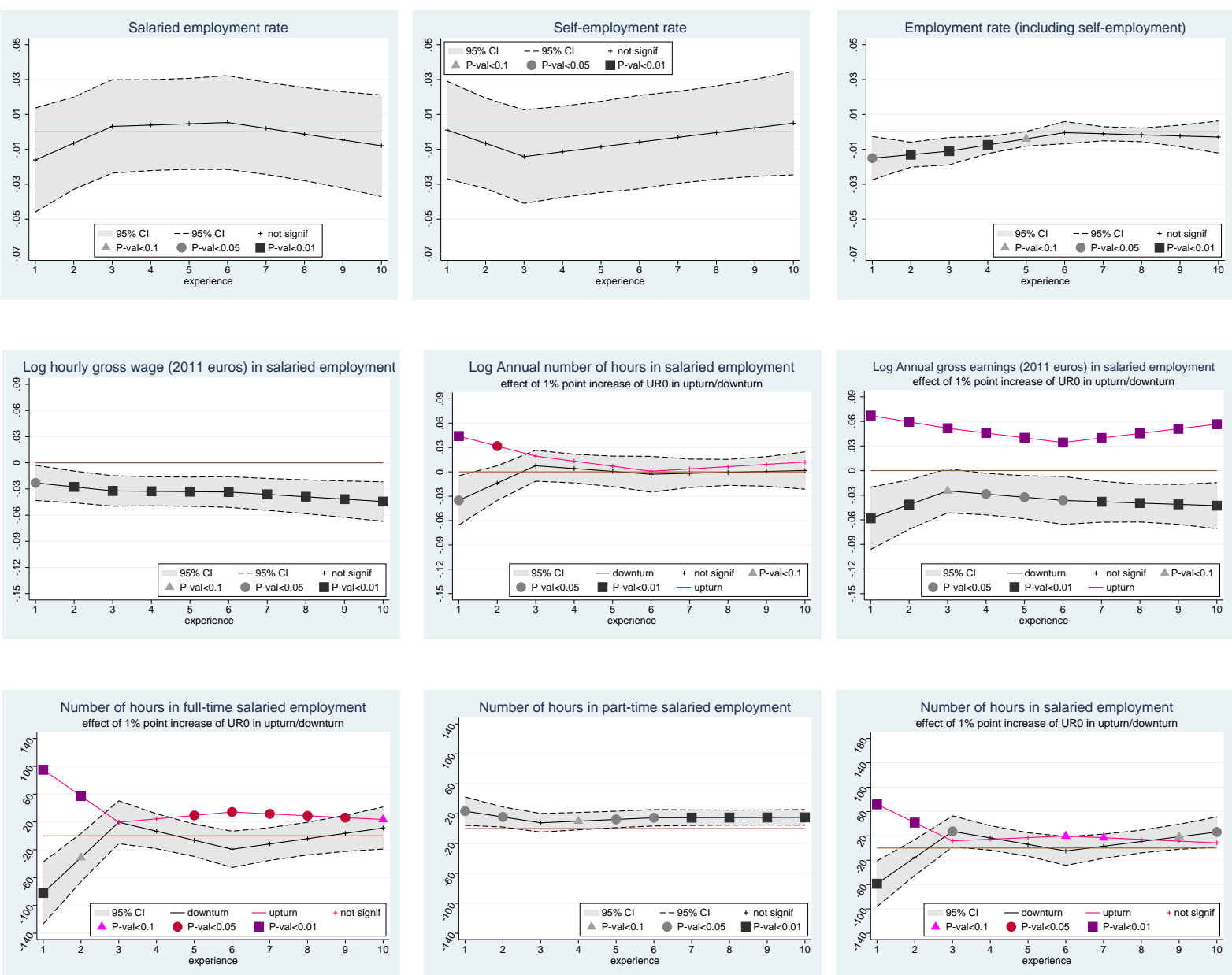

The figure displays for the high educated the effect of increasing (decreasing in case of an upturn) the provincial unemployment rate at graduation by one $p p$ on the main outcomes of interest. The effects reported in top, middle and bottom panel result each time from two-step FGLS estimates of a SUR model on the first two outcomes described in detail in Section 5.2 The effects for the third outcome are obtained from the following adding up constraints: salaried employment+self-employment=overall employment; log hourly wage+log hours worked=log earnings; FT hours worked + PT hours worked=total hours worked. Table C.1 in Appendix C reports the corresponding point estimates displayed in the figure. 
in the following year. This may mitigate the initial wage penalty. However, in contrast to what is observed in more flexible labor markets (see e.g. Oreopoulos et al., 2012), in all subsequent years the unlucky graduates are not more (nor less) mobile than the lucky ones ${ }^{39}$ In line with this and the aforementioned evidence, the median wage in the recruiting firm is during the first ten years of labor market experience persistently smaller (on average $3.3 \%$ ) for each $p p$ increase of the unemployment rate at graduation. Hence, the unfortunate workers remain trapped in lower quality jobs.

Finally, on average $3.2 \%$ of the high educated move to another province each year. This is more than double as much as for the low educated. Nevertheless, we cannot find any evidence that geographic mobility is significantly related to the unemployment rate at graduation (see Table C.2.

\subsection{Sensitivity Analysis}

In Supplementary Online Appendix S.8 we report a number of sensitivity analyses for the six main outcomes that we considered in the analysis: the three indicators of employment, log hourly wage, log annual hours worked and log annual earnings. In a first sensitivity analysis we include dummy variables for each number of completed years of education as individual control variables in the first step regression. If the timing of education is unrelated to the unemployment rate, the inclusion of these variables should not affect the conclusions. This is what we find.

Second, we contrast the provincial to the national model. In the national model identification relies on the calender time variation of the unemployment rate at labor market entry in deviation from the parametrically specified (linear spline) dependence of graduation time. Because of this strong identifying assumption, we do not find a complete correspondence between the models, but overall the patterns of the effects are quite comparable, certainly if we account for the higher degree of imprecision in the national model. In particular, we find a larger negative effect on hours worked (and, hence in earnings) in the first year after graduation, and for the high educated also in years nine and ten. In addition, the effect on the self-employment rate of the high educated displays a strong positive trend from experience years six to ten, which we did not observe in the provincial model.

Third, for the dichotomous indicators we always estimated a linear probability model in the first step. As a sensitivity analysis, we estimate a probit model in the first step, and, subsequently, the covariate-adjusted group-time means on the aggregate regressors by FGLS. In Tables S.20 and S.22 of the Supplementary Online Appendix we report the partial effects on the probability of employment for each year of potential experience, where the other aggregate

\footnotetext{
${ }^{39}$ Sector mobility is never affected by the unemployment rate at graduation. Hence, in the first year of potential experience the high educated significantly move between firms within the same sector. Results are available upon request.
} 
regressors are evaluated at their sample mean. These partial effects are very similar to the ones that we found in the benchmark linear probability model. The main difference is that the estimates of probit model are much less precise.

The benchmark model was estimated by FGLS on the second step regression model (4). This should generally deliver more precise estimates than those obtained by OLS with cluster robust standard errors in this second step. For the continuous outcomes, FGLS results indeed generally in more precise estimates than OLS. Exceptions are the effects on the log hourly wage for the low educated (and only to slight extent for the high educated) ${ }^{40}$ However, this can be a consequence of the log hourly wage being estimated jointly with log annual hours worked in a SUR regression. The larger standard errors in the wage equation are more than compensated by the higher precision of the effects in the hours equation. For the dichotomous variables, FGLS delivers in this particular application somewhat less precise estimates of the effects of interest. Only for the effect on the overall employment rate of the high educated the standard errors obtained by FGLS are consistently smaller.

Finally, we compare OLS applied to the one-step regression model (1) to OLS applied in the second step. In both cases we cluster standard errors by province and year of graduation combination $(g p)$. Point estimates are very comparable, but because of the small number of clusters, we expect the standard errors of effects in the one-step OLS regression to be downward biased. This is what we find for the continuous outcomes. However, for the dichotomous outcomes this is only the case for the effect on the overall employment rate of the low educated. This suggests that for this particular application the downward bias is important for the continuous outcomes, but not for the dichotomous ones.

\section{Conclusion}

In this paper we studied the short- and long-run impacts of graduating in a recession in Flanders, the largest region in Belgium that is characterized by a very rigid labor market. We analyzed these impacts separately for high and low educated workers, because labor market institutions are different for white and blue collar workers, for which the aforementioned education types are very good proxies. While EPL is very strict for white collars and relatively weak for blue collars, the minimum wage is binding for the latter group and not for the former. Consequently, while a recession at graduation is found to have a persistent negative effect on earnings for both groups, the high educated experience a persistent negative effect on the hourly wage and not on the annual hours worked, and the reverse holds for the low educated. These results are corroborated by a comprehensive set of sensitivity analyses. Concretely, a typical recession, which increases the unemployment rate by $1.4 \mathrm{pp}$, would induce the annual hours worked (and, hence, earnings)

\footnotetext{
${ }^{40}$ Notice, as mentioned in Section 6.1 the effect of a $p p$ increase of the unemployment rate at graduation is now found to be significantly negative as from seven years after labor market entry for low educated.
} 
of the low educated to decrease by about $4.5 \%$ up to twelve years after graduation, while the hourly wage (and, hence, earnings) of the high educated would be roughly $6 \%$ lower than in case of a status quo ten years after labor market entry. The Great Recession of 2008 resulted in an increase of the unemployment rate of $1.6 \mathrm{pp}$, so that we predict that the negative consequences for the cohorts that graduated during the Great Recession will be about $15 \%(\cong 0.2 / 1.4)$ higher than the aforementioned ones.

Our results add to the evidence that labor market rigidity leads to much more persistent negative effects of recessions at labor market entry (Genda et al., 2010; Kawaguchi and Murao, 2014) and to fundamentally unjust (since it is induced by just bad luck) inequality between generations. At the same time our findings for low educated demonstrates that relaxing EPL alone is not sufficient to avoid persistence. Broader structural policy reforms seem to be required, which are much more difficult to implement.

\section{Acknowledgements}

We wish to thank Matteo Picchio, William Parienté, Dieter Verhaest, Bruno Van der Linden, and the participants to the seminars at Ghent University (internal seminar), IZA (Bonn), Department of Economics of the Marche Polytechnic University in Ancona, Louvain-la-Neuve (Doctoral Workshops), as well as the participants to the $X X V I I I^{\text {th }}$ National Conference of Labour Economics in Rome (27-28 September 2013) and to the Annual Meeting of the Association of Southern European Economic Theorists (ASSET), Bilbao (7-9 November 2013) for their valuable comments and discussions. We are grateful to the Cross Roads Bank for Social Security and the "Steunpunt Studie- en Schoolloopbanen" for the availability of the data. Corinna Ghirelli acknowledges financial support from the Special Research Fund ("BOF") of Ghent University, as well as from the National Bank of Belgium (project code 05Y00110). The usual disclaimer applies. 


\section{APPENDIX}

\section{A Descriptive Statistics.}

Table A.1: Descriptive Statistics of Individual Controls in the Retained Sample.

\begin{tabular}{|c|c|c|c|c|c|c|}
\hline \multicolumn{7}{|c|}{ Low Educated } \\
\hline Variable & Obs & Mean & Std. Dev. & Min & Max & Label $^{\S}$ \\
\hline live in single-parent & 1885 & 0.119 & 0.324 & 0 & 1 & 1 if live with single parent at age17(Dec) \\
\hline not live with parents & 1885 & 0.064 & 0.244 & 0 & 1 & 1 if not live with either parents at age17(Dec) \\
\hline HH members aged $0-11^{\dagger}$ & 1885 & 0.247 & 0.625 & 0 & 7 & $\mathrm{nr}$ of other HH members aged0-11 at age17(Dec) \\
\hline HH members aged $12-17$ & 1885 & 0.507 & 0.687 & 0 & 7 & $\mathrm{nr}$ of other HH members aged12-17 at age17(Dec) \\
\hline HH members aged 18-29 & 1885 & 0.520 & 0.729 & 0 & 8 & $\mathrm{nr}$ of other HH members aged18-29 at age17(Dec) \\
\hline HH members aged $30-64$ & 1885 & 1.890 & 0.400 & 0 & 5 & $\mathrm{nr}$ of other HH members aged30-64 at age17(Dec) \\
\hline HH members aged $65+$ & 1885 & 0.037 & 0.207 & 0 & 2 & $\mathrm{nr}$ of other HH members aged $65+$ at age $17(\mathrm{Dec})$ \\
\hline father education $^{\dagger \dagger}$ & 1885 & 4.582 & 3.196 & 0 & 13 & father completed education since age12 \\
\hline mother education $^{\dagger \dagger}$ & 1885 & 4.199 & 3.066 & 0 & 13 & mother completed education since age 12 \\
\hline years of delay in sec.edu ${ }^{\ddagger}$ & 1885 & 0.825 & 0.843 & -1 & 4 & years of delay at age17(Aug) \\
\hline general edu ${ }^{\S \S}$ & 1885 & 0.108 & 0.310 & 0 & 1 & 1 if general edu at age17(Aug) \\
\hline technical edu & 1885 & 0.379 & 0.485 & 0 & 1 & 1 if technical edu at age17(Aug) \\
\hline vocational edu & 1885 & 0.412 & 0.492 & 0 & 1 & 1 if vocational edu at age17(Aug) \\
\hline apprenticeship/PT voc edu & 1885 & 0.101 & 0.302 & 0 & 1 & 1 if apprent./PT vocational at age17(Aug) \\
\hline birth cohort76 $6^{\ddagger \ddagger}$ & 1885 & 0.333 & 0.471 & 0 & 1 & 1 if born in 1976 \\
\hline birth cohort78 & 1885 & 0.333 & 0.471 & 0 & 1 & 1 if born in 1978 \\
\hline birth cohort80 & 1885 & 0.334 & 0.472 & 0 & 1 & 1 if born in 1980 \\
\hline \multicolumn{7}{|c|}{ High Educated } \\
\hline Variable & Obs & Mean & Std. Dev. & Min & Max & Label \\
\hline live in single-parent & 1629 & 0.079 & 0.270 & 0 & 1 & 1 if live with single parent at age17(Dec) \\
\hline not live with parents & 1629 & 0.027 & 0.162 & 0 & 1 & 1 if not live with either parents at age17(Dec) \\
\hline HH members aged $0-11$ & 1629 & 0.154 & 0.424 & 0 & 3 & $\mathrm{nr}$ of other HH members aged0-11 at age17(Dec) \\
\hline HH members aged $12-17$ & 1629 & 0.578 & 0.687 & 0 & 4 & $\mathrm{nr}$ of other $\mathrm{HH}$ members aged12-17 at age17(Dec) \\
\hline HH members aged $18-29$ & 1629 & 0.583 & 0.717 & 0 & 4 & $\mathrm{nr}$ of other HH members aged18-29 at age17(Dec) \\
\hline HH members aged 30-64 & 1629 & 1.926 & 0.299 & 1 & 4 & $\mathrm{nr}$ of other HH members aged30-64 at age17(Dec) \\
\hline HH members aged $65+$ & 1629 & 0.029 & 0.185 & 0 & 2 & $\mathrm{nr}$ of other $\mathrm{HH}$ members aged $65+$ at age $17(\mathrm{Dec})$ \\
\hline father education & 1629 & 7.031 & 3.239 & 0 & 13 & father completed education since age12 \\
\hline mother education & 1629 & 6.382 & 2.935 & 0 & 13 & mother completed education since age 12 \\
\hline years of delay in sec.edu & 1629 & 0.260 & 0.540 & -1 & 3 & years of delay at age17(Aug) \\
\hline general edu & 1629 & 0.652 & 0.477 & 0 & 1 & 1 if general edu at age17(Aug) \\
\hline technical edu & 1629 & 0.339 & 0.473 & 0 & 1 & 1 if technical edu at age17(Aug) \\
\hline vocational edu & 1629 & 0.009 & 0.092 & 0 & 1 & 1 if vocational edu at age 17 (Aug) \\
\hline apprenticeship/PT voc edu & 1629 & 0.001 & 0.025 & 0 & 1 & 1 if apprent./PT vocational at age17(Aug) \\
\hline birth cohort76 & 1629 & 0.330 & 0.470 & 0 & 1 & 1 if born in 1976 \\
\hline birth cohort78 & 1629 & 0.341 & 0.474 & 0 & 1 & 1 if born in 1978 \\
\hline birth cohort 80 & 1629 & 0.330 & 0.470 & 0 & 1 & 1 if born in 1980 \\
\hline
\end{tabular}

$\S$ "at age17(Dec)" ("at age17(Aug)") means that the variable is measured in December (August) of the year when the individual turns age 17 .

$\dagger$ HH refers to household.

$\dagger \dagger$ It measures the number of years of education successfully attained since age 12 .

$\ddagger$ The variable measures the educational progression at age 17: a value of 0 means that the student is on time; -1 means that the student has skipped one academic year; positive values indicate the number of repeated grades.

$\S \S I n$ the first step of the main analysis general education is the reference category.

$\$ \ddagger I n$ the first step of the main analysis birth cohort76 is the reference category. 
Table A.2: Descriptive Statistics Regarding the Selection Rules for the Benchmark Outcomes in the Provincial Model*

\begin{tabular}{|c|c|c|c|c|}
\hline \multirow{2}{*}{$\begin{array}{l}\text { Graduation period: } \\
\text { Outcomes }^{\S}\end{array}$} & \multicolumn{2}{|c|}{$\begin{array}{c}\text { Low educated } \\
\text { 1994-2001 }\end{array}$} & \multicolumn{2}{|c|}{$\begin{array}{c}\text { High educated } \\
\text { 1997-2004 }\end{array}$} \\
\hline & Continuous & Discrete & Continuous & Discrete \\
\hline Number of cells (total) & 420 & 420 & 350 & 350 \\
\hline Number of dropped cells & 42 & 138 & 27 & 109 \\
\hline Number of retained cells & 378 & 282 & 323 & 241 \\
\hline \multicolumn{5}{|l|}{ Statistics on dropped cells } \\
\hline Mean size dropped cells & 10.29 & 30.97 & 13.11 & 27.95 \\
\hline Max size dropped cells & 15 & 111 & 15 & 66 \\
\hline \multicolumn{5}{|l|}{ Statistics on retained cells } \\
\hline Mean size retained cells & 45.19 & 57.56 & 37.64 & 47.48 \\
\hline Max size retained cells & 104 & 111 & 79 & 89 \\
\hline \multicolumn{5}{|c|}{ Statistics on retained cells for which $16 \leq N_{\text {gpt }}<30$ (continuous) or $E X P_{g p t}^{\dagger}<5$ (discrete) } \\
\hline Number of retained cells & 94 & 38 & 123 & 46 \\
\hline Avg size retained cells & 23.06 & 45.08 & 23.08 & 34.07 \\
\hline Max size retained cells & 29 & 111 & 29 & 66 \\
\hline \multicolumn{5}{|l|}{ P-value joint test for selectivity ${ }^{\S}$} \\
\hline Specification used for log hourly wage & 0.322 & & 0.637 & \\
\hline Specification used for log hours worked & 0.091 & & 0.105 & \\
\hline Specification used for all discrete outcomes & & 0.379 & & 0.207 \\
\hline
\end{tabular}

* To avoid too small cell sizes, we impose the following selection rules. For continuous variables, drop cells gpt with size $N_{g p t}<16$. For discrete variables, drop cells $g p t$ with the smallest $E X P_{g p t}^{\dagger}$ until at most $20 \%$ of the retained cells are such that EXP $P_{\text {gpt }}<5$ (Cochran 1954).

$\dagger E X P_{g p t}=\min \left\{N_{g p t} P_{g p t}, N_{g p t}\left(1-P_{g p t}\right)\right\}$, where $P_{g p t}$ denotes the probability of success and which can be estimated by aggregating the individual predictions of this probability in the first step OLS regression of Eq. 3. to the cell level gpt. Notice that the aforementioned minimum is calculated for each outcome in the SUR and that the selection rule is applied on the basis of the smallest minimum across these outcomes.

$\S$ The benchmark continuous outcomes in the SUR are log hourly wage and log hours worked in salaried employment, and the benchmark discrete variables are salaried employment and self-employment. The statistics in the table refer to one outcome, since they are identical for each outcome retained in a SUR.

$\ddagger$ These are groups that would have been dropped according to the more stringent selection rules, i.e. $N_{g p t}<30$ for the continuous outcomes and $E X P_{g p t}<5$ for the discrete outcomes.

$\S \S$ The test for selectivity is based on a one-step regression of an indicator that is set to one if the individual belongs to a cell that is dropped according to the selection rules mentioned in $(*)$. Standard errors are clustered by group $g p$, which therefore tends to over-reject the null hypothesis that all the coefficients of the linear spline that interacts the unemployment rate at graduation are jointly significantly different from zero. We impose the same restrictions on the regression model (1) as we do for each benchmark outcome that we retain in the SUR (see Table B.1). Consequently, since different sets of restrictions are imposed on the regression of log hourly wage than on that of log hours worked, we report two P-values for the continuous outcomes. For the discrete outcomes the same restrictions are imposed on both outcomes, so that only one $\mathrm{P}$-value is reported. 


\section{B Results for the Main Outcomes of Interest of Low Educated.}

Table B.1: Effect of a One $p p$ Increase of the Unemployment Rate at Graduation on Main Outcomes: Low Educated

\begin{tabular}{|c|c|c|c|c|c|c|c|c|c|}
\hline Outcomes & salaried & self-empl. & overall empl. & log wage & $\log$ hours $^{\S}$ & log earnings & FT hours & PT hours & Total hours \\
\hline \multicolumn{10}{|l|}{ Imposed Restrictions: } \\
\hline Effect URate at grad. symm. up/downturn & yes & yes & - & yes & no & - & yes & yes & - \\
\hline Effect Current URate over $\exp =0$ & yes & yes & - & no & no & - & no & no & - \\
\hline Spline for calendar year FE & yes & yes & - & no & no & - & no & no & - \\
\hline Effect of prov-time trends $=0$ & yes & yes & - & no & no & - & no & no & - \\
\hline Test joint signif. all imposed restr.(P-val) & \multicolumn{2}{|c|}{0.286} & - & \multicolumn{2}{|c|}{0.155} & - & \multicolumn{2}{|c|}{0.268} & - \\
\hline$P$-value of chi2 test & \multicolumn{2}{|c|}{0.341} & & \multicolumn{2}{|c|}{0.000} & - & \multicolumn{2}{|c|}{0.000} & - \\
\hline WSSR (2nd step) & \multicolumn{2}{|c|}{331} & - & \multicolumn{2}{|c|}{1289} & - & \multicolumn{2}{|c|}{1519} & - \\
\hline Obs $(2 \text { nd step })^{\dagger}$ & \multicolumn{2}{|c|}{375} & - & \multicolumn{2}{|c|}{756} & - & \multicolumn{2}{|c|}{754} & - \\
\hline Parameters (2nd step) & \multicolumn{2}{|c|}{54} & - & \multicolumn{2}{|c|}{88} & - & \multicolumn{2}{|c|}{86} & - \\
\hline Level of clustering & no & no & no & $g * p$ & $g * p$ & $g * p$ & $g * p$ & $g * p$ & $g * p$ \\
\hline Potential experience & (1) & $(2)$ & (3) & $(4)$ & $(5)$ & $(6)$ & $(7)$ & $(8)$ & (9) \\
\hline 1 & $\begin{array}{l}-0.017 \\
(0.018)\end{array}$ & $\begin{array}{c}0.036 \\
(0.018)\end{array}$ & $\begin{array}{c}0.018 \\
(0.015)\end{array}$ & $\begin{array}{c}0.005 \\
(0.013)\end{array}$ & $\begin{array}{l}-0.044 \\
(0.022)\end{array}$ & $\begin{array}{l}-0.039 \\
(0.026)\end{array}$ & $\begin{array}{l}-123.741 \\
(33.386)\end{array}$ & $\begin{array}{c}36.280 \\
(12.419)\end{array}$ & $\begin{array}{l}-87.462 \\
(26.467)\end{array}$ \\
\hline 2 & $\begin{array}{l}-0.011 \\
(0.015)\end{array}$ & $\begin{array}{c}0.021 \\
(0.015)\end{array}$ & $\begin{array}{c}0.010 \\
(0.009)\end{array}$ & $\begin{array}{l}-0.001 \\
(0.010)\end{array}$ & $\begin{array}{l}-0.035 \\
(0.020)\end{array}$ & $\begin{array}{l}-0.036 \\
(0.023)\end{array}$ & $\begin{array}{l}-82.608 \\
(28.233)\end{array}$ & $\begin{array}{l}15.700 \\
(9.828)\end{array}$ & $\begin{array}{l}-66.908 \\
(23.051)\end{array}$ \\
\hline 3 & $\begin{array}{l}-0.005 \\
(0.015)\end{array}$ & $\begin{array}{c}0.007 \\
(0.015)\end{array}$ & $\begin{array}{c}0.002 \\
(0.009)\end{array}$ & $\begin{array}{l}-0.006 \\
(0.009)\end{array}$ & $\begin{array}{l}-0.026 \\
(0.022)\end{array}$ & $\begin{array}{l}-0.033 \\
(0.022)\end{array}$ & $\begin{array}{l}-41.474 \\
(24.951)\end{array}$ & $\begin{array}{l}-4.879 \\
(9.819)\end{array}$ & $\begin{array}{l}-46.354 \\
(22.119)\end{array}$ \\
\hline 4 & $\begin{array}{l}-0.002 \\
(0.015)\end{array}$ & $\begin{array}{c}0.001 \\
(0.014)\end{array}$ & $\begin{array}{l}-0.001 \\
(0.007)\end{array}$ & $\begin{array}{l}-0.008 \\
(0.008)\end{array}$ & $\begin{array}{l}-0.026 \\
(0.019)\end{array}$ & $\begin{array}{l}-0.034 \\
(0.019)\end{array}$ & $\begin{array}{l}-30.805 \\
(22.293)\end{array}$ & $\begin{array}{l}-6.854 \\
(8.855)\end{array}$ & $\begin{array}{l}-37.659 \\
(19.123)\end{array}$ \\
\hline 5 & $\begin{array}{c}0.000 \\
(0.014)\end{array}$ & $\begin{array}{l}-0.005 \\
(0.014)\end{array}$ & $\begin{array}{l}-0.005 \\
(0.006)\end{array}$ & $\begin{array}{l}-0.009 \\
(0.008)\end{array}$ & $\begin{array}{l}-0.026 \\
(0.016)\end{array}$ & $\begin{array}{l}-0.035 \\
(0.017)\end{array}$ & $\begin{array}{l}-20.135 \\
(20.394)\end{array}$ & $\begin{array}{l}-8.829 \\
(8.282)\end{array}$ & $\begin{array}{l}-28.964 \\
(16.793)\end{array}$ \\
\hline 6 & $\begin{array}{c}0.002 \\
(0.015)\end{array}$ & $\begin{array}{l}-0.010 \\
(0.014)\end{array}$ & $\begin{array}{l}-0.008 \\
(0.008)\end{array}$ & $\begin{array}{l}-0.011 \\
(0.007)\end{array}$ & $\begin{array}{l}-0.025 \\
(0.014)\end{array}$ & $\begin{array}{l}-0.036 \\
(0.015)\end{array}$ & $\begin{array}{c}-9.466 \\
(19.475)\end{array}$ & $\begin{array}{l}-10.804 \\
(8.183)\end{array}$ & $\begin{array}{l}-20.270 \\
(15.434)\end{array}$ \\
\hline 7 & $\begin{array}{c}0.002 \\
(0.014)\end{array}$ & $\begin{array}{l}-0.009 \\
(0.014)\end{array}$ & $\begin{array}{l}-0.007 \\
(0.006)\end{array}$ & $\begin{array}{l}-0.008 \\
(0.007)\end{array}$ & $\begin{array}{l}-0.025 \\
(0.012)\end{array}$ & $\begin{array}{l}-0.033 \\
(0.014)\end{array}$ & $\begin{array}{l}-23.298 \\
(18.219)\end{array}$ & $\begin{array}{l}-2.250 \\
(7.363)\end{array}$ & $\begin{array}{l}-25.548 \\
(14.743)\end{array}$ \\
\hline 8 & $\begin{array}{c}0.002 \\
(0.014)\end{array}$ & $\begin{array}{l}-0.007 \\
(0.014)\end{array}$ & $\begin{array}{l}-0.005 \\
(0.005)\end{array}$ & $\begin{array}{l}-0.006 \\
(0.007)\end{array}$ & $\begin{array}{l}-0.025 \\
(0.012)\end{array}$ & $\begin{array}{l}-0.031 \\
(0.014)\end{array}$ & $\begin{array}{l}-37.129 \\
(18.010)\end{array}$ & $\begin{array}{c}6.304 \\
(7.409)\end{array}$ & $\begin{array}{l}-30.826 \\
(14.801)\end{array}$ \\
\hline 9 & $\begin{array}{c}0.002 \\
(0.015)\end{array}$ & $\begin{array}{l}-0.005 \\
(0.014)\end{array}$ & $\begin{array}{l}-0.004 \\
(0.006)\end{array}$ & $\begin{array}{l}-0.003 \\
(0.008)\end{array}$ & $\begin{array}{l}-0.025 \\
(0.013)\end{array}$ & $\begin{array}{l}-0.028 \\
(0.016)\end{array}$ & $\begin{array}{l}-50.961 \\
(18.883)\end{array}$ & $\begin{array}{l}14.858 \\
(8.307)\end{array}$ & $\begin{array}{l}-36.103 \\
(15.598)\end{array}$ \\
\hline 10 & $\begin{array}{c}0.003 \\
(0.015)\end{array}$ & $\begin{array}{l}-0.009 \\
(0.014)\end{array}$ & $\begin{array}{l}-0.006 \\
(0.005)\end{array}$ & $\begin{array}{l}-0.006 \\
(0.008)\end{array}$ & $\begin{array}{l}-0.027 \\
(0.010)\end{array}$ & $\begin{array}{l}-0.033 \\
(0.014)\end{array}$ & $\begin{array}{l}-44.904 \\
(19.371)\end{array}$ & $\begin{array}{l}15.268 \\
(7.981)\end{array}$ & $\begin{array}{l}-29.637 \\
(16.251)\end{array}$ \\
\hline 11 & $\begin{array}{c}0.004 \\
(0.015)\end{array}$ & $\begin{array}{l}-0.013 \\
(0.014)\end{array}$ & $\begin{array}{l}-0.009 \\
(0.006)\end{array}$ & $\begin{array}{l}-0.009 \\
(0.009)\end{array}$ & $\begin{array}{l}-0.030 \\
(0.010)\end{array}$ & $\begin{array}{l}-0.039 \\
(0.014)\end{array}$ & $\begin{array}{l}-38.848 \\
(21.167)\end{array}$ & $\begin{array}{l}15.678 \\
(8.434)\end{array}$ & $\begin{array}{l}-23.170 \\
(17.862)\end{array}$ \\
\hline 12 & $\begin{array}{c}0.006 \\
(0.015)\end{array}$ & $\begin{array}{l}-0.017 \\
(0.014)\end{array}$ & $\begin{array}{l}-0.011 \\
(0.007)\end{array}$ & $\begin{array}{l}-0.012 \\
(0.010)\end{array}$ & $\begin{array}{l}-0.033 \\
(0.012)\end{array}$ & $\begin{array}{l}-0.045 \\
(0.017)\end{array}$ & $\begin{array}{l}-32.791 \\
(23.977)\end{array}$ & $\begin{array}{l}16.088 \\
(9.556)\end{array}$ & $\begin{array}{l}-16.703 \\
(20.202)\end{array}$ \\
\hline
\end{tabular}

Standard errors between parentheses. The table shows the effect for low educated of increasing the provincial unemployment rate at graduation by one $p p$ on the mentioned outcomes. The reported estimates result from predictions based on the estimates of the linear spline in potential experience $f_{g}(e)$ that multiplies the provincial unemployment rate at graduation $u_{g p}$ in Eq. 4. Since the outcomes satisfy adding-up constraints (salaried employment+self-employment=overall employment; log hourly wage+log hours worked=log earnings; FT hours worked+PT hours worked=total hours worked), the estimates are each time obtained from a two-step FGLS SUR on the first two outcomes in the sum described in detail in Section 5.2 and briefly below. Effects on the third outcome (the sum) are then obtained from the adding-up constraints. First step: Eq. (3) is estimated by OLS. Standard errors are clustered at the individual level. Second step: Eq. (4) is estimated by FGLS, where the inverse of the variance matrix of the $\hat{\mu}_{g p t}$ in the first step is used as weight. Depending on the outcome, we impose restrictions which cannot be jointly rejected at the $5 \%$ level: these restrictions are listed in the top panel of the table. If the $\chi 2$ goodness-of-fit statistic rejects the model (P-value $>0.05)$, standard errors clustered at the $g p$ level are reported; otherwise conventional ones.

$\S$ For log hours worked the following additional restriction (not mentioned in the table) is also imposed: $\beta_{g 2}=0$, i.e. the slope of the linear spline remains fixed after 6 years of experience. This restriction cannot be rejected.

$\dagger$ The lower number of observations for the discrete outcomes in the second step reflects both that a different number of cells was dropped to ensure large enough cell sizes and the fact that the variance matrix of the $\hat{\mu}_{g p t}$ in the first step is singular so that we had to use the generalized inverse of the variance as weight in the second step (see Section 5.2 for more details).

Column 5 and 6 report the effects of interests in downturn: the effects in case of an upturn are different, but not reported. All other columns report the effect of interest independently of the business cycle, since this restriction is not rejected. 
Table B.2: Effect on Mobility and Firm Quality: Low educated

\begin{tabular}{|c|c|c|c|}
\hline Outcomes & geographical mobility $\S$ & firm mobility & median daily wage in the firm \\
\hline \multicolumn{4}{|l|}{ Imposed Restrictions: } \\
\hline Effect URate at grad. symmetric up/downturn & no & yes & yes \\
\hline Effect Current URate over exp $=0$ & yes & yes & yes \\
\hline Spline for calendar year FE & yes & no & no \\
\hline Spline for exp FE & yes & no & no \\
\hline Effect prov-time trends $=0$ & yes & yes & no \\
\hline Test joint signif. all imposed restr.(P-val) & 0.478 & 0.252 & 0.854 \\
\hline P-value of chi2 test & - & 0.001 & 0.001 \\
\hline WSSR (2nd step) & - & 413 & 422 \\
\hline Obs (2nd step) & - & 360 & 378 \\
\hline Parameters (2nd step) & - & 35 & 39 \\
\hline Test joint signif. URate_grad (P-val) & 0.126 & 0.720 & - \\
\hline Level of clustering & $i$ & $g * p$ & $g * p$ \\
\hline Estimation approach & one-step & two-step & two-step \\
\hline Potential experience & $(1)$ & $(2)$ & (3) \\
\hline \multirow[t]{2}{*}{1} & 0.000 & 0.008 & -0.014 \\
\hline & $(0.003)$ & $(0.019)$ & $(0.011)$ \\
\hline \multirow[t]{2}{*}{2} & -0.001 & 0.005 & -0.016 \\
\hline & $(0.002)$ & $(0.012)$ & $(0.010)$ \\
\hline \multirow[t]{2}{*}{3} & -0.001 & 0.001 & -0.018 \\
\hline & $(0.003)$ & $(0.013)$ & $(0.009)$ \\
\hline \multirow[t]{2}{*}{4} & -0.001 & -0.001 & -0.016 \\
\hline & $(0.002)$ & $(0.010)$ & $(0.008)$ \\
\hline \multirow[t]{2}{*}{5} & 0.000 & -0.003 & -0.015 \\
\hline & $(0.003)$ & $(0.008)$ & $(0.008)$ \\
\hline \multirow[t]{2}{*}{6} & 0.000 & -0.005 & -0.014 \\
\hline & $(0.003)$ & $(0.009)$ & $(0.008)$ \\
\hline \multirow[t]{2}{*}{7} & 0.002 & 0.001 & -0.015 \\
\hline & $(0.003)$ & $(0.008)$ & $(0.008)$ \\
\hline \multirow[t]{2}{*}{8} & 0.003 & 0.006 & -0.015 \\
\hline & $(0.003)$ & $(0.009)$ & $(0.007)$ \\
\hline \multirow[t]{2}{*}{9} & 0.004 & 0.012 & -0.016 \\
\hline & $(0.004)$ & $(0.011)$ & $(0.007)$ \\
\hline \multirow[t]{2}{*}{10} & 0.003 & 0.009 & -0.017 \\
\hline & $(0.004)$ & $(0.010)$ & $(0.007)$ \\
\hline \multirow[t]{2}{*}{11} & 0.002 & 0.006 & -0.017 \\
\hline & $(0.004)$ & $(0.010)$ & $(0.008)$ \\
\hline \multirow[t]{2}{*}{12} & 0.001 & 0.003 & -0.018 \\
\hline & $(0.005)$ & $(0.011)$ & $(0.008)$ \\
\hline
\end{tabular}

Standard errors between parentheses. The table shows the effect for low educated of increasing the provincial unemployment rate at graduation by one $p p$ on the mentioned outcomes. The reported estimates result from predictions based on the estimates of the linear spline in potential experience $f_{g}(e)$ that multiplies the provincial unemployment rate at graduation $u_{g p}$ in Eq. 44. Since the outcomes need not satisfy adding-up constraints, except for geographic mobility (see $\S$ ) the estimates are obtained from a two-step FGLS on each outcome separately. The estimation procedure is described in detail in Section 5.2 and briefly below. First step: Eq. 3 is estimated by OLS. Standard errors are clustered at the individual level. Second step: Eq. 45 is estimated by FGLS, where the inverse of the variance matrix of the $\hat{\mu}_{g p t}$ in the first step is used as weight. Depending on the outcome, we impose restrictions which cannot be jointly rejected at the $5 \%$ level: these restrictions are listed in the top panel of the table. If the $\chi 2$ goodness-of-fit statistic rejects the model (P-value $>0.05$ ), standard errors clustered at the $g p$ level are reported; otherwise conventional ones.

$\S$ Notice that the effect on geographic mobility between provinces is estimated in one step, since virtually no cell satisfies the rule of Cochran (1954) discussed in Section 5.2 In the one-step approach both clustering at the individual and the $g * p$-level tends to over-reject. Since the P-value of the joint test of significance of the unemployment rate at graduation is higher at the individual than at the $g * p$ level we report the former.

Column 1 reports the effects of interests in downturn: the effects in case of an upturn are different, but not reported. All other columns report the effect of interest independently of the business cycle, since this restriction is not rejected. 


\section{Results for the Main Outcomes of Interest of High Educated.}

Table C.1: Effect of a One $p p$ Increase of the Unemployment Rate at Graduation on Main Outcomes: High educated

\begin{tabular}{|c|c|c|c|c|c|c|c|c|c|}
\hline Outcomes & salaried & self-empl. & overall empl. & log wage & $\log$ hours & log earnings & FT hours & PT hours & Total hours \\
\hline \multicolumn{10}{|l|}{ Imposed Restrictions: } \\
\hline Effect URate at grad. symm. up/downturn & yes & yes & - & yes & no & & no & yes & - \\
\hline Effect Current URate over $\exp =0$ & yes & yes & - & yes & yes & & no & yes & - \\
\hline Spline for calendar year FE & yes & yes & - & no & no & & no & no & - \\
\hline Effect of prov-time trends $=0$ & yes & yes & - & no & no & & no & no & - \\
\hline Test joint signif. all imposed restr.(P-val) & \multicolumn{2}{|c|}{0.494} & - & \multicolumn{2}{|c|}{0.309} & - & \multicolumn{2}{|c|}{0.390} & - \\
\hline P-value of chi2 test & \multicolumn{2}{|c|}{0.329} & - & \multicolumn{2}{|c|}{$2.89 \mathrm{E}-34$} & - & \multicolumn{2}{|c|}{$4.48 \mathrm{E}-32$} & - \\
\hline WSSR (2nd step) & \multicolumn{2}{|c|}{310} & - & \multicolumn{2}{|c|}{1084} & - & \multicolumn{2}{|c|}{1059} & - \\
\hline Obs $(2 \text { nd step })^{\dagger}$ & \multicolumn{2}{|c|}{262} & - & \multicolumn{2}{|c|}{646} & - & \multicolumn{2}{|c|}{646} & - \\
\hline Parameters (2nd step) & \multicolumn{2}{|c|}{48} & - & \multicolumn{2}{|c|}{75} & - & \multicolumn{2}{|c|}{78} & - \\
\hline Level of clustering & no & no & no & $g * p$ & $g * p$ & $g * p$ & $g * p$ & $g * p$ & $g * p$ \\
\hline Potential experience & (1) & $(2)$ & (3) & (4) & $(5)$ & (6) & $(7)$ & $(8)$ & (9) \\
\hline 1 & $\begin{array}{l}-0.016 \\
(0.015)\end{array}$ & $\begin{array}{c}0.001 \\
(0.014)\end{array}$ & $\begin{array}{l}-0.015 \\
(0.006)\end{array}$ & $\begin{array}{l}-0.023 \\
(0.010)\end{array}$ & $\begin{array}{l}-0.035 \\
(0.015)\end{array}$ & $\begin{array}{l}-0.058 \\
(0.019)\end{array}$ & $\begin{array}{l}-81.986 \\
(22.004)\end{array}$ & $\begin{array}{l}23.301 \\
(9.359)\end{array}$ & $\begin{array}{l}-58.685 \\
(18.501)\end{array}$ \\
\hline 2 & $\begin{array}{l}-0.006 \\
(0.013)\end{array}$ & $\begin{array}{l}-0.007 \\
(0.013)\end{array}$ & $\begin{array}{l}-0.013 \\
(0.004)\end{array}$ & $\begin{array}{l}-0.028 \\
(0.009)\end{array}$ & $\begin{array}{l}-0.014 \\
(0.011)\end{array}$ & $\begin{array}{l}-0.041 \\
(0.015)\end{array}$ & $\begin{array}{l}-31.209 \\
(17.068)\end{array}$ & $\begin{array}{l}15.540 \\
(6.611)\end{array}$ & $\begin{array}{l}-15.669 \\
(14.479)\end{array}$ \\
\hline 3 & $\begin{array}{c}0.003 \\
(0.014)\end{array}$ & $\begin{array}{l}-0.014 \\
(0.014)\end{array}$ & $\begin{array}{l}-0.011 \\
(0.004)\end{array}$ & $\begin{array}{l}-0.032 \\
(0.009)\end{array}$ & $\begin{array}{c}0.008 \\
(0.009)\end{array}$ & $\begin{array}{l}-0.025 \\
(0.013)\end{array}$ & $\begin{array}{c}19.569 \\
(15.191)\end{array}$ & $\begin{array}{c}7.778 \\
(6.132)\end{array}$ & $\begin{array}{c}27.347 \\
(12.584)\end{array}$ \\
\hline 4 & $\begin{array}{c}0.004 \\
(0.013)\end{array}$ & $\begin{array}{l}-0.011 \\
(0.013)\end{array}$ & $\begin{array}{l}-0.007 \\
(0.003)\end{array}$ & $\begin{array}{l}-0.033 \\
(0.008)\end{array}$ & $\begin{array}{c}0.004 \\
(0.009)\end{array}$ & $\begin{array}{l}-0.029 \\
(0.012)\end{array}$ & $\begin{array}{c}6.612 \\
(12.390)\end{array}$ & $\begin{array}{l}10.017 \\
(5.697)\end{array}$ & $\begin{array}{l}16.629 \\
(9.889)\end{array}$ \\
\hline 5 & $\begin{array}{c}0.005 \\
(0.013)\end{array}$ & $\begin{array}{l}-0.009 \\
(0.013)\end{array}$ & $\begin{array}{l}-0.004 \\
(0.002)\end{array}$ & $\begin{array}{l}-0.033 \\
(0.008)\end{array}$ & $\begin{array}{c}0.001 \\
(0.009)\end{array}$ & $\begin{array}{l}-0.032 \\
(0.013)\end{array}$ & $\begin{array}{c}-6.345 \\
(11.468)\end{array}$ & $\begin{array}{l}12.256 \\
(5.445)\end{array}$ & $\begin{array}{c}5.911 \\
(9.492)\end{array}$ \\
\hline 6 & $\begin{array}{c}0.005 \\
(0.014)\end{array}$ & $\begin{array}{l}-0.006 \\
(0.014)\end{array}$ & $\begin{array}{c}0.000 \\
(0.003)\end{array}$ & $\begin{array}{l}-0.033 \\
(0.009)\end{array}$ & $\begin{array}{l}-0.003 \\
(0.011)\end{array}$ & $\begin{array}{l}-0.036 \\
(0.014)\end{array}$ & $\begin{array}{l}-19.302 \\
(12.835)\end{array}$ & $\begin{array}{l}14.495 \\
(5.403)\end{array}$ & $\begin{array}{c}-4.807 \\
(11.630)\end{array}$ \\
\hline 7 & $\begin{array}{c}0.002 \\
(0.013)\end{array}$ & $\begin{array}{l}-0.003 \\
(0.013)\end{array}$ & $\begin{array}{l}-0.001 \\
(0.002)\end{array}$ & $\begin{array}{l}-0.036 \\
(0.009)\end{array}$ & $\begin{array}{l}-0.002 \\
(0.009)\end{array}$ & $\begin{array}{l}-0.038 \\
(0.012)\end{array}$ & $\begin{array}{l}-11.662 \\
(11.589)\end{array}$ & $\begin{array}{l}14.625 \\
(5.111)\end{array}$ & $\begin{array}{c}2.963 \\
(9.769)\end{array}$ \\
\hline 8 & $\begin{array}{l}-0.001 \\
(0.014)\end{array}$ & $\begin{array}{c}0.000 \\
(0.014)\end{array}$ & $\begin{array}{l}-0.002 \\
(0.002)\end{array}$ & $\begin{array}{l}-0.039 \\
(0.010)\end{array}$ & $\begin{array}{l}-0.001 \\
(0.008)\end{array}$ & $\begin{array}{l}-0.040 \\
(0.011)\end{array}$ & $\begin{array}{c}-4.022 \\
(11.567)\end{array}$ & $\begin{array}{l}14.755 \\
(4.964)\end{array}$ & $\begin{array}{l}10.733 \\
(9.198)\end{array}$ \\
\hline 9 & $\begin{array}{l}-0.005 \\
(0.014)\end{array}$ & $\begin{array}{c}0.002 \\
(0.014)\end{array}$ & $\begin{array}{l}-0.002 \\
(0.003)\end{array}$ & $\begin{array}{l}-0.042 \\
(0.010)\end{array}$ & $\begin{array}{c}0.001 \\
(0.009)\end{array}$ & $\begin{array}{l}-0.041 \\
(0.012)\end{array}$ & $\begin{array}{c}3.618 \\
(12.775)\end{array}$ & $\begin{array}{l}14.885 \\
(4.975)\end{array}$ & $\begin{array}{c}18.504 \\
(10.137)\end{array}$ \\
\hline 10 & $\begin{array}{l}-0.008 \\
(0.015)\end{array}$ & $\begin{array}{c}0.005 \\
(0.015)\end{array}$ & $\begin{array}{l}-0.003 \\
(0.005)\end{array}$ & $\begin{array}{l}-0.044 \\
(0.011)\end{array}$ & $\begin{array}{c}0.002 \\
(0.011)\end{array}$ & $\begin{array}{l}-0.043 \\
(0.014)\end{array}$ & $\begin{array}{c}11.258 \\
(14.919)\end{array}$ & $\begin{array}{l}15.016 \\
(5.142)\end{array}$ & $\begin{array}{c}26.274 \\
(12.244)\end{array}$ \\
\hline
\end{tabular}

Standard errors between parentheses. The table shows the effect for low educated of increasing the provincial unemployment rate at graduation by one $p p$ on the mentioned outcomes. The reported estimates result from predictions based on the estimates of the linear spline in potential experience $f_{g}(e)$ that multiplies the provincial unemployment rate at graduation $u_{g p}$ in Eq. (4). Since the outcomes satisfy adding-up constraints (salaried employment+self-employment=overall employment; log hourly wage+log hours worked=log earnings; FT hours worked+PT hours worked=total hours worked), the estimates are each time obtained from a two-step FGLS SUR on the first two outcomes in the sum described in detail in Section 5.2 and briefly below. Effects on the third outcome (the sum) are then obtained from the adding-up constraints. First step: Eq. (3) is estimated by OLS. Standard errors are clustered at the individual level. Second step: Eq. (4) is estimated by FGLS, where the inverse of the variance matrix of the $\hat{\mu}_{g p t}$ in the first step is used as weight. Depending on the outcome, we impose restrictions which cannot be jointly rejected at the $5 \%$ level: these restrictions are listed in the top panel of the table. If the $\chi 2$ goodness-of-fit statistic rejects the model (P-value $>0.05)$, standard errors clustered at the $g p$ level are reported; otherwise conventional ones.

$\dagger$ The lower number of observations for the discrete outcomes in the second step reflects both that a different number of cells was dropped to ensure large enough cell sizes and the fact that the variance matrix of the $\hat{\mu}_{g p t}$ in the first step is singular so that we had to use the generalized inverse of the variance as weight in the second step (see Section 5.2 for more details).

Columns 5-7 and 9 report the effects of interests in downturn: the effects in case of an upturn are different, but not reported. All other columns report the effect of interest independently of the business cycle, since this restriction is not rejected. 
Table C.2: Effect on Mobility and Firm Quality: High educated

\begin{tabular}{|c|c|c|c|}
\hline Outcomes & geographical mobility ${ }^{\S}$ & firm mobility & median daily wage in the firm \\
\hline \multicolumn{4}{|l|}{ Imposed Restrictions: } \\
\hline Effect URate at grad. symmetric up/downturn & yes & yes & no \\
\hline Effect Current URate over $\exp =0$ & yes & yes & yes \\
\hline Spline for calendar year FE & no & no & no \\
\hline Spline for exp FE & yes & no & no \\
\hline Effect prov-time trends $=0$ & yes & yes & yes \\
\hline Test joint signif. all imposed restr.(P-val) & 0.273 & 0.471 & 0.236 \\
\hline P-value of chi2 test & - & 0.964 & 0.028 \\
\hline WSSR (2nd step) & - & 214 & 336 \\
\hline Obs (2nd step) & - & 285 & 323 \\
\hline Parameters (2nd step) & - & 32 & 35 \\
\hline Test joint signif. URate_grad (P-val) & 0.495 & 0.165 & - \\
\hline Level of clustering & $i$ & no & $g * p$ \\
\hline Estimation approach & one-step & two-step & two-step \\
\hline potential exp & $(1)$ & $(2)$ & $(3)$ \\
\hline \multirow[t]{2}{*}{1} & 0.009 & 0.026 & -0.037 \\
\hline & $(0.006)$ & $(0.013)$ & $(0.007)$ \\
\hline \multirow[t]{2}{*}{2} & 0.005 & 0.008 & -0.038 \\
\hline & $(0.004)$ & $(0.009)$ & $(0.006)$ \\
\hline \multirow[t]{2}{*}{3} & 0.001 & -0.009 & -0.039 \\
\hline & $(0.005)$ & $(0.011)$ & $(0.007)$ \\
\hline \multirow[t]{2}{*}{4} & 0.001 & -0.007 & -0.035 \\
\hline & $(0.004)$ & $(0.008)$ & $(0.006)$ \\
\hline \multirow[t]{2}{*}{5} & 0.001 & -0.006 & -0.031 \\
\hline & $(0.004)$ & $(0.008)$ & $(0.006)$ \\
\hline \multirow[t]{2}{*}{6} & 0.001 & -0.004 & -0.027 \\
\hline & $(0.004)$ & $(0.010)$ & $(0.007)$ \\
\hline \multirow[t]{2}{*}{7} & 0.002 & -0.005 & -0.029 \\
\hline & $(0.004)$ & $(0.008)$ & $(0.007)$ \\
\hline \multirow[t]{2}{*}{8} & 0.003 & -0.006 & -0.031 \\
\hline & $(0.004)$ & $(0.009)$ & $(0.006)$ \\
\hline \multirow[t]{2}{*}{9} & 0.005 & -0.007 & -0.033 \\
\hline & $(0.004)$ & $(0.011)$ & $(0.007)$ \\
\hline \multirow[t]{2}{*}{10} & 0.006 & -0.008 & -0.035 \\
\hline & $(0.005)$ & $(0.015)$ & $(0.007)$ \\
\hline
\end{tabular}

Standard errors between parentheses. The table shows the effect for low educated of increasing the provincial unemployment rate at graduation by one $p p$ on the mentioned outcomes. The reported estimates result from predictions based on the estimates of the linear spline in potential experience $f_{g}(e)$ that multiplies the provincial unemployment rate at graduation $u_{g p}$ in Eq. 4. Since the outcomes need not satisfy adding-up constraints, except for geographic mobility (see §) the estimates are obtained from a two-step FGLS on each outcome separately. The estimation procedure is described in detail in Section 5.2 and briefly below. First step: Eq. 3 is estimated by OLS. Standard errors are clustered at the individual level. Second step: Eq. (4) is estimated by FGLS, where the inverse of the variance matrix of the $\hat{\mu}_{g p t}$ in the first step is used as weight. Depending on the outcome, we impose restrictions which cannot be jointly rejected at the $5 \%$ level: these restrictions are listed in the top panel of the table. If the $\chi^{2}$ goodness-of-fit statistic rejects the model (P-value $>0.05$ ), standard errors clustered at the $g p$ level are reported; otherwise conventional ones.

$\S$ Notice that the effect on geographic mobility between provinces is estimated in one step, since virtually no cell satisfies the rule of Cochran (1954) discussed in Section 5.2 In the one-step approach both clustering at the individual and the $g * p$-level tends to over-reject. Since the P-value of the joint test of significance of the unemployment rate at graduation is higher at the individual than at the $g * p$ level we report the former.

Column 3 reports the effects of interests in downturn: the effects in case of an upturn are different, but not reported. All other columns report the effect of interest independently of the business cycle, since this restriction is not rejected. 


\section{References}

Altonji, J. G., L. B. Kahn, and J. D. Speer (2014). Chashier or Consultant? Entry Labor Market Conditions, Field of Study, and Career Success. NBER Working Paper Series 20531, National Bureau of Economic Research, Cambridge (MA).

Amemiya, T. and F. Nold (1975). A Modified Logit Model. The Review of Economics and Statistics 57(2), 255-257.

Angrist, J. D. and J.-S. Pischke (2009). Mostly Harmless Econometrics: An Empiricist's Companion. Princeton University Press.

Arulampalam, W. (2001). Is Unemployment Really Scarring? Effects of Unemployment Experiences on Wages. The Economic Journal 111(475), 585-606.

Baert, S., B. Cockx, and D. Verhaest (2013). Overeducation at the Start of the Career: Stepping Stone or Trap? Labour Economics 25, 123-140.

Baker, G., M. Gibbs, and B. Holmstrom (1994). The Wage Policy of a Firm. The Quarterly Journal of Economics 109(4), 921-955.

Barten, A. P. (1969). Maximum Likelihood Estimation of a Complete System of Demand Equations. European Economic Review 1(1), 7-73.

Beaudry, P. and J. DiNardo (1991). The Effect of Implicit Contracts on the Movement of Wages Over the Business Cycle: Evidence from Micro Data. Journal of Political Economy 99(4), 665-688.

Berndt, E. R. and N. E. Savin (1975). Estimation and Hypothesis Testing in Singular Equation Systems with Autoregressive Disturbances. Econometrica 43(5/6), 937-958.

Bertrand, M., E. Duflo, and S. Mullainathan (2004). How Much Should We Trust DifferencesIn-Differences Estimates? The Quarterly Journal of Economics 119(1), 249-275.

Biewen, M. and S. Steffes (2010). Unemployment persistence: Is there evidence for stigma effects? Economics Letters 106(3), 188-190.

Brewer, M., T. F. Crossley, and R. Joyce (2013). Inference with Difference-in-Differences Revisited. Discussion Paper 7742, IZA, Bonn.

Brunner, B. and A. Kuhn (2014). The impact of labor market entry conditions on initial job assignment and wages. Journal of Population Economics 27(3), 705-738.

Cahuc, P. and S. Carcillo (2014). Alléger le coût du travail pour augmenter l'emploi : les clés de la réussite. ÉTUDE Avril 2014, Institut Montaigne, Paris. 
Cameron, A. C., J. B. Gelbach, and D. L. Miller (2008). Bootstrap-Based Improvements for Inference with Clustered Errors. Review of Economics and Statistics 90(3), 414-427.

Cameron, A. C. and D. L. Miller (2015). A Practitioner's Guide to Cluster-Robust Inference. Journal of Human Resources, forthcoming.

Cochran, W. G. (1954). Some methods for strengthening the common $\chi^{2}$ tests. Biometrics 10(4), 417-451.

Cockx, B. (2013a). Youth Unemployment in Belgium: Diagnosis and Key Remedies. IZA Policy Paper 66, IZA, Bonn.

Cockx, B. (2013b). Youth Unemployment in Belgium: Diagnosis and Key Remedies. Intereconomics 48(4), 202-209.

Cockx, B. and M. Dejemeppe (2005). Duration Dependence in the Exit Rate out of Unemployment in Belgium: Is It True or Spurious? Journal of Applied Econometrics 20(1), 1-23.

Cockx, B. and M. Dejemeppe (2012). Monitoring job search effort: An evaluation based on a regression discontinuity design. Labour Economics 19(5), 729-737.

Deaton, A. (1997). The Analysis of Household Surveys: A Microeconometric Approach to Development Policy, Chapter 2.7, pp. 101-109. Baltimore, Maryland: Johns Hopkins University Press.

Devereux, P. J. and R. A. Hart (2007). The Spot Market Matters: Evidence on Implicit Contracts from Britain. Scottish Journal of Political Economy 54(5), 661-683.

European Commission (2010). Self-Employment in Europe 2010. European Commission, Directorate-General for Employment, Social Affairs and Equal Opportunities, Unit D.2.

Fairlie, R. W. (2013). Entrepreneurship, Economic Conditions, and the Great Recession. Journal of Economics \& Management Strategy 22(2), 207-231.

Fuss, C. (2009). What Is the Most Flexible Component of Wage Bill Adjustment? Evidence from Belgium. Labour Economics 16(3), 320-329.

Gaini, M., A. Leduc, and A. Vicard (2012). A scarred generation? French evidence on young people entering into a tough labour market. Working Paper of the DESE G 2012 / 5, Institut National de la Statistique et des Études Économiques, France.

Genda, Y., A. Kondo, and S. Ohta (2010). Long-Term Effects of a Recession at Labor Market Entry in Japan and the United States. Journal of Human Resources 45(1), 157-196. 
Gibbons, R. and M. Waldman (2004). Task-Specific Human Capital. The American Economic Review 94(2), 203-207.

Gibbons, R. and M. Waldman (2006). Enriching a Theory of Wage and Promotion Dynamics inside Firms. Journal of Labor Economics 24(1), 59-107.

Gregg, P. (2001, November). The Impact of Youth Unemployment on Adult Unemployment in the NCDS. The Economic Journal 111(475), 626-563.

Gregg, P. and E. Tominey (2005). The wage scar from male youth unemployment. Labour Economics 12(4), 487-509.

Hagedorn, M. and I. Manovskii (2013). Job Selection and Wages over the Business Cycle. American Economic Review 103(2), 771-803.

Hansen, C. B. (2007). Generalized Least Squares Inference in Panel and Multilevel Models with Serial Correlation and Fixed Effects. Journal of Econometrics 140(2), 670-694.

Hanushek, E. A., L. Woessmann, and L. Zhang (2011). General Education, Vocational Education, and Labor-Market Outcomes over the Life-Cycle. IZA Discussion Paper 6083, IZA, Bonn.

Heckman, J. (1974). Shadow Prices, Market Wages, and Labor Supply. Journal of Econometrics 42(4), 679-694.

Hershbein, B. J. (2012). Graduating High School in a Recession: Work, Education, and Home Production. The B.E. Journal of Economic Analysis 63 Policy 12(1), Article 3.

Hijzen, A. and D. Venn (2011). The Role of Short-Time Work Schemes during the 200809 Recession. OECD Social, Employment and Migration Working Papers No. 115, OECD Publishing.

Høj, J. (2013). Enhancing the Inclusiveness of the Labour Market in Belgium. OECD Economics Department Working Papers No. 1009, OECD Publishing.

Jenkins, S. P. (1995). Easy Estimation Methods for Discrete-Time Duration Models. Oxford Bulletin of Economics and Statistics 57(1), 129-136.

Kahn, L. B. (2010). The Long-Term Labor Market Consequences of Graduating from College in a Bad Economy. Labour Economics 17(2), 303-316.

Kawaguchi, D. and T. Murao (2014). Labor Market Institutions and Long-Term Effects of Youth Unemployment. IZA Discussion Paper 8156, IZA, Bonn. 
Kiefer, N. M. (1988). Analysis of Grouped Duration Data. In N. U. Prabhu (Ed.), Statistical Inference from Stochastic Processes. American Mathematical Society, Providence.

Kilponen, J. and T. Santavirta (2010). New Evidence on Implicit Contracts from Linked Employer-Employee Data. Scandinavian Journal of Economics 112(4), 864-883.

Kondo, A. (2007). Differential Effects of Graduating during a Recession across Race and Gender. ISERP Working Paper 07-05, Institute for Social and Economic Research and Policy (ISERP), Columbia University.

Kramarz, F. and T. Philippon (2001). The Impact of Differential Payroll Tax Subsidies on Minimum Wage Employment. Journal of Public Economics 82(1), 115-146.

Kroft, K., F. Lange, and M. J. Notowidigdo (2013). Duration Dependence and Labor Market Conditions: Evidence from a Field Experiment. The Quarterly Journal of Economics 128(3), $1123-1167$.

Kwon, I., E. M. Milgrom, and S. Hwang (2010). Cohort Effects in Promotions and Wages: Evidence from Sweden and the United States. Journal of Human Resources 45(3), 772-808.

Liu, K., K. G. Salvanes, and E. Sørensen (2012). Good Skills in Bad Times: Cyclical Skill Mismatch and the Long-Term Effects of Graduating in a Recession. IZA Discussion Paper 6820, IZA, Bonn.

Mansour, H. (2009). The Career Effects of Graduating from College in a Bad Economy: The Role of Workers Ability. Mimeo, University of Colorado Denver and DIW Berlin.

Mroz, T. A. and T. H. Savage (2006). The Long-Term Effects of Youth Unemployment. Journal of Human Resources 41(2), 259-293.

Neumark, D. and W. L. Wascher (2008). Minimum Wages. Cambridge, MA: MIT Press.

OECD (2007). Activating the Unemployed: What Do Countries Do. In Employment Outlook, Chapter 5, pp. 207-242. Paris: OECD.

OECD (2012). Equity and Quality in Education. Supporting Disadvantaged Pupils and Schools. Paris: OECD.

OECD (2013). Employment Outlook. Paris: OECD.

Oreopoulos, P., T. von Wachter, and A. Heisz (2012). The Short- and Long-Term Career Effects of Graduating in a Recession. American Economic Journal: Applied Economics 4(1), 1-29.

Oreopoulos, P., T. v. Wachter, and A. Heisz (2008). The Short- and Long-Term Career Effects of Graduating in a Recession: Hysteresis and Heterogeneity in the Market for College Graduates. IZA Discussion Paper 3578, IZA, Bonn. 
Pérez, E. and Y. Yao (2015). Can institutional reform reduce job destruction and unemployment duration? Yes it can. Empirical Economics, 1-23.

Raaum, O. and K. Røed (2006). Do Business Cycle Conditions at the Time of Labor Market Entry Affect Future Employment Prospects? The Review of Economics and Statistics 88(2), $193-210$.

Rycx, F. and S. Kampelmann (2013). Who Earns Minimum Wages in Europe? New Evidence Based on Household Surveys. CEB Working Paper 13-002, Université Libre de Bruxelles.

Schmillen, A. and M. Umkehrer (2013). The Scars of Youth: Effects of Early-Career Unemployment on Future Unemployment Experience. IAB Discussion Paper 201306, Institute for Employment Research, Nuremberg.

SONAR (2003). Hoe maken de jongeren de overgang van school naar werk? Basisrapportering Cohorte 1978 (eerste golf). Technical report, Leuven: Steunpunt WAV.

SONAR (2004a). Hoe maken de jongeren de overgang van school naar werk? Basisrapportering Cohorte 1976 (tweede golf). Technical report, Leuven: Steunpunt WAV.

SONAR (2004b). Hoe maken de jongeren de overgang van school naar werk? Cohorte 1980 (eerste golf). Technisch rapport. Technical report, Leuven: Steunpunt WAV.

Speer, J. D. (2014). Wages, Hours, and the School-to-Work transition: The Consequences of leaving School in a Recession for Less-Educated Men. Mimeo, University of Memphis.

Stevens, K. (2008). Adverse Economic Conditions at Labour Market Entry: Permanent Scars or Rapid Catch-up? Mimeo, University of Sydney.

Taylor, M. (2013). The labour market impacts of leaving education when unemployment is high: evidence from Britain. ISER Working Paper Series 2013-12, Institute for Social and Economic Research, University of Essex.

Topel, R. H. and M. P. Ward (1992). Job Mobility and the Careers of Young Men. The Quarterly Journal of Economics 107(2), 439-79.

Wooldridge, J. M. (2006). Cluster-Sample Methods in Applied Econometrics: An Extended Analysis. Mimeo, Department of Economics, Michigan State University.

Wooldridge, J. M. (2010). Econometric Analysis of Cross Section And Panel Data (second ed.). The MIT Press, Cambridge, MA.

Yu, L., P. F. Orazem, and R. W. Jolly (2014). Entrepreneurship over the business cycle. Economics Letters 122(2), 105-110. 
Zellner, A. (1962). An Efficient Method of Estimating Seemingly Unrelated Regressions and Tests for Aggregation Bias. Journal of the American Statistical Association 57(298), 348368. 